\title{
Termite Prevention and Control ${ }^{1}$
}

\author{
F. M. Oi, J. Davis, J. McConnell, J. Corbus, N. Nelson, and M. Atkinson²
}

\section{Introduction}

The global economic impact of termites is estimated to be at $\$ 40$ billion annually. Subterranean termites are responsible for about $80 \%$ of the total economic impact (Rust and $\mathrm{Su}$ 2012). Your home is a large investment. Termite prevention and control should be a priority and incorporated into your general home maintenance plan, which may include an annual renewal inspection by a trained and licensed termite inspector.

Termites generally require a pest management professional for control, but there are many things that you can do to prevent infestations. This guide is intended to help you make an informed choice on the best termite protection for you and contains the following information.

\section{Termites 101, an Overview}

\section{Summary of Termite Types and Methods of Control}

Termite species can be regional, but termite groups (e.g., dampwood, drywood, subterranean) and control methods are nationally recognized. Check with your state and local UF/IFAS Extension offices if you have questions about identification and control.

Two of the most common groups of termites that homeowners encounter are drywood termites and subterranean termites. Dampwood termites can be occasionally found in homes (Figure 1). The "higher termites," conehead (Nasutitermes corniger) and the Florida dark-wing termites (Amitermes floridensis), have been found infesting structures in Florida only, and only occasionally (Figures 14-17). Table 1 contains a summary of control options for the most common wood-destroying organisms.

\section{Where Termites are Found}

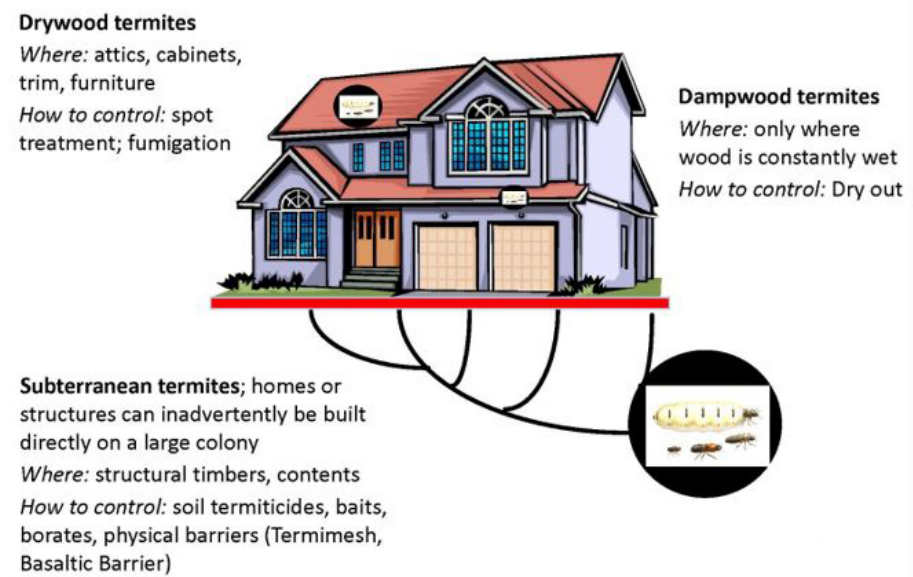

Figure 1. A summary of where termites might be found in a structure and a brief description of control options.

Credits: Nan-Yao Su, UF/IFAS

1. This document is ENY-2044, one of a series of the Entomology and Nematology Department, UF/IFAS Extension. Original publication date March 2020. Visit the EDIS website at https://edis.ifas.ufl.edu for the currently supported version of this publication.

2. F. M. Oi, associate Extension scientist, Entomology and Nematology Department; J. Davis, director, UF/IFAS Extension Sumter and Hernando Counties; J. McConnell, commercial/residential horticulture agent II, UF/IFAS Extension Bay County; J. Corbus, family and consumer sciences Extension agent IV, UF/IFAS Extension Washington and Holmes Counties; N. Nelson, family and consumer sciences agent I, UF/IFAS Extension Manatee County; and M. Atkinson, environmental horticulture agent II, UF/IFAS Extension Manatee County; UF/IFAS Extension, Gainesville, FL 32611.

The Institute of Food and Agricultural Sciences (IFAS) is an Equal Opportunity Institution authorized to provide research, educational information and other services

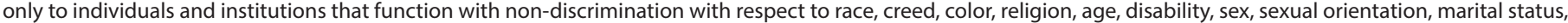

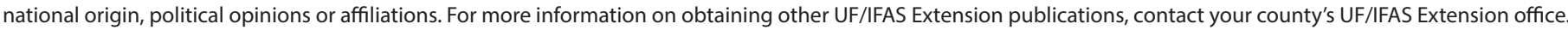
U.S. Department of Agriculture, UF/IFAS Extension Service, University of Florida, IFAS, Florida A \& M University Cooperative Extension Program, and Boards of County Commissioners Cooperating. Nick T. Place, dean for UF/IFAS Extension. 


\section{What is at risk of termite damage in my home?}

Termites have a unique ability to digest cellulose, which is one of the most abundant materials on Earth. Cellulose can be found in wood and paper products. Thus, termites can damage structural timbers such as wooden studs, other framing material, and wooden trim such as baseboards and crown molding (Figure 2).

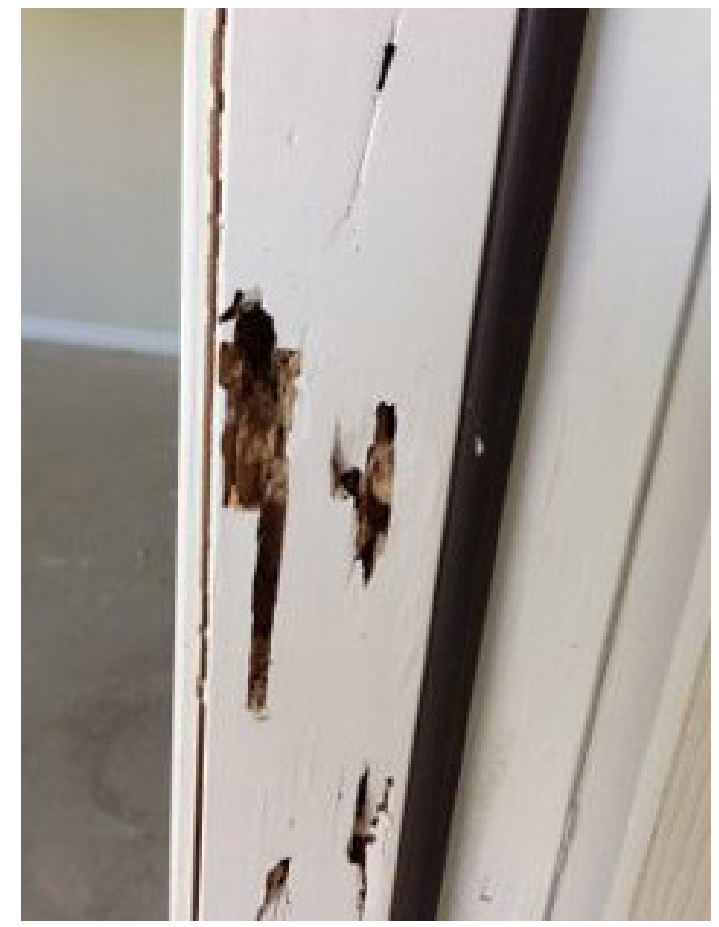

Figure 2. Termite damage on a door frame. Door frames are common access points. Doors often sit on expansion joints that allow subterranean termites to find their way in.

Credits: Faith Oi, UF/IFAS

Termites also can damage the contents of homes, including cabinetry, furniture, books, and stored items (Figure 3).

Termites are known to damage non-cellulosic material as well. They can easily tunnel through construction elements such as rigid foam board insulation and spray foam insulation (Figure 4).

Be aware that many pest control companies will not place a warranty on homes with spray foam insulation (Figure 5).

An example of a consumer notice published by a state agency on why spray foam can be excluded from warranties can be found here (http://agr.georgia.gov/Data/Sites/1/ media/ag_plantindustry/structural_pest_control/structural_pest_control_commission/files/Notice-18-04-SprayFoam-Insulation-and-Pest-Management.pdf). In brief, spray foam can create a situation where thorough inspections and effective termite treatment cannot be conducted.

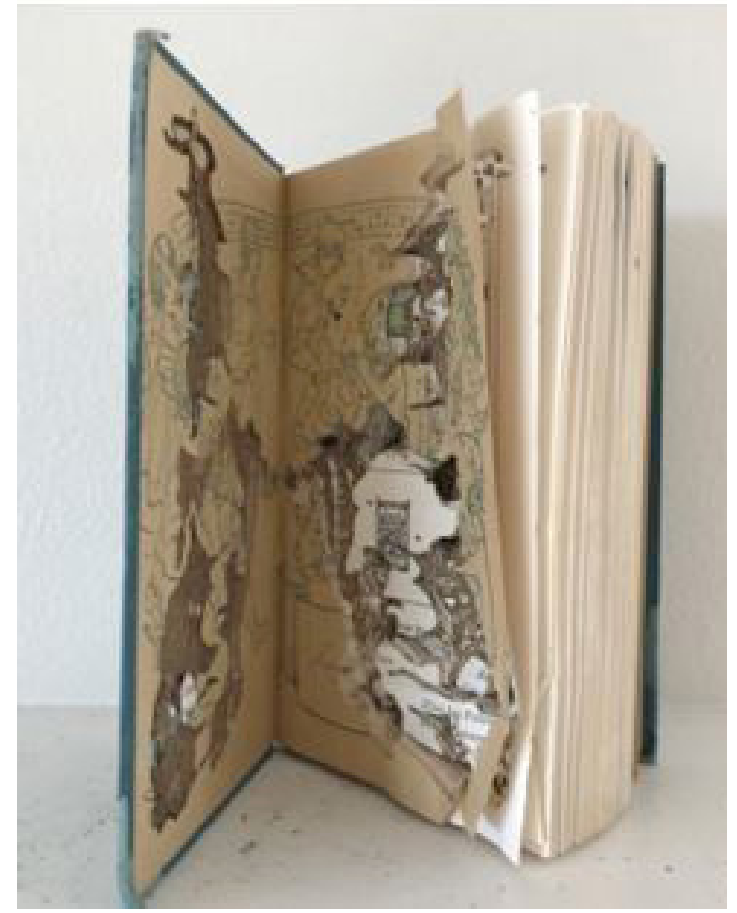

Figure 3. Book with subterranean termite damage. Notice mud on inside cover.

Credits: Faith Oi, UF/IFAS

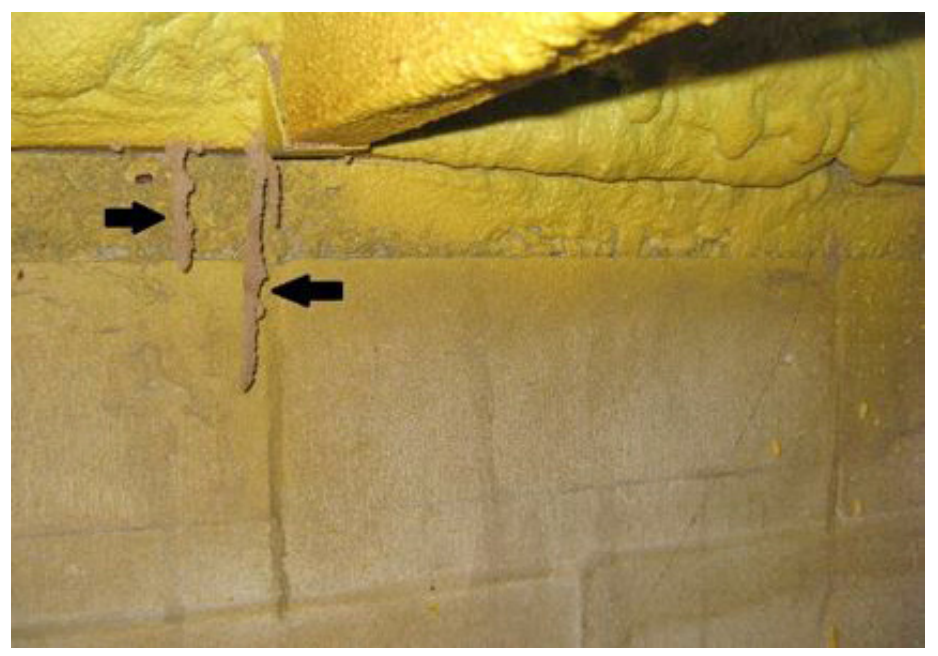

Figure 4. Arrows denote subterranean termite mud tubes emerging from behind spray foam insulation installed over floor joists in crawlspace.

Credits: Faith Oi, UF/IFAS

\section{One Reason That Termites Are Difficult to Control: The Colony}

Termites live in colonies that can contain hundreds to millions of individuals, depending on the species. With some termites, such as the Formosan subterranean termites, the colony foraging territory can cover over an acre. In other species such as the drywood, Cryptotermes, it may take years for damage to be detected. 


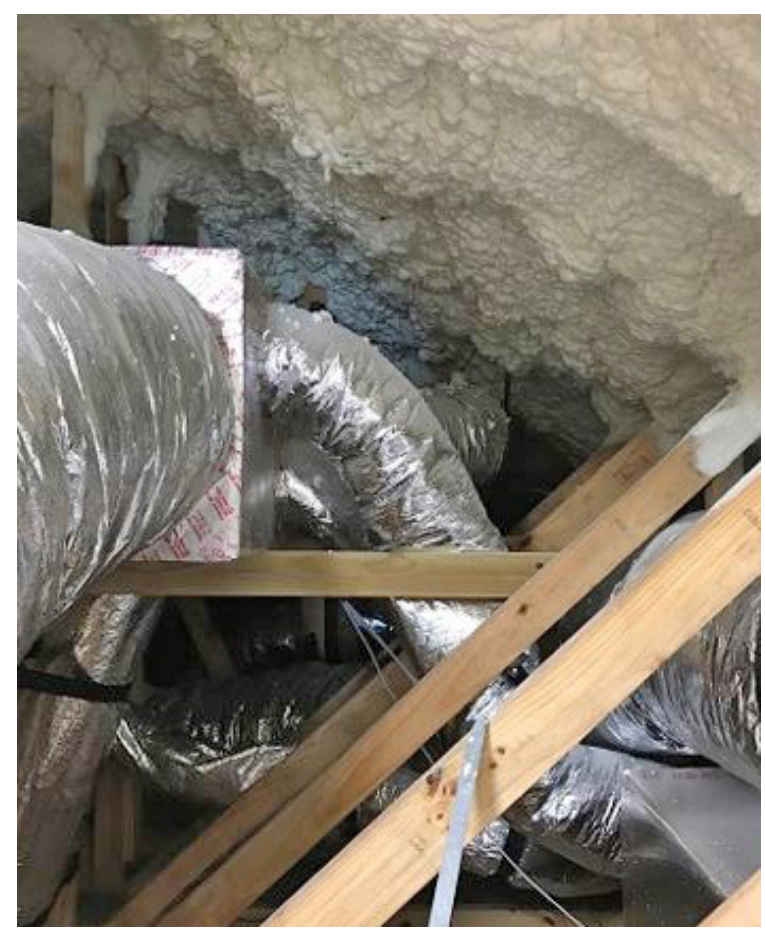

Figure 5. Spray foam insulation that obscures inspections and duct work that makes this space inaccessible for inspections.

Credits: Faith Oi, UF/IFAS

The colony contains different castes (i.e., forms): workers, soldiers, and reproductive (Figures 18, 26, and 42)

- Workers are the most numerous and do the damage in the colony with their chewing mouthparts. They have been called "white ants" because of their cream-colored appearance. They are about $1 / 8$ of an inch long.

- Soldiers have "sclerotized" (darkened) heads and make up a much smaller percentage of the colony. They defend the colony and have other important functions. They are about $1 / 8$ of an inch long.

- "Swarmers" are a winged reproductive form, also called alates. Alates with wings are about $1 / 4$ to $3 / 8$ of an inch long and are the most helpful form for termite identification, followed by soldiers, then workers. Swarmers are only present during the spring and possibly fall.

\section{Termite Identification}

The most important part of termite control is obtaining a correct identification. Treatments for different species are drastically different, and most of them are costly. It is important to differentiate correctly between termites and ants and between different groups (Figure 6).

Free termite identification. The termite researchers at the UF/IFAS Fort Lauderdale Research and Education Center will identify your termites for free! Follow the directions at this link to submit a sample: https://flrec.ifas.ufl.edu/ termites-in-florida/send-samples/. They maintain a termite

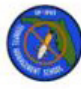

\section{Termite vs. Ant}

- Termites

- Order Blattodea

- Infraorder Isoptera

- No waist

- Forewing and hindwing about equal

- Moniliform (beaded) antennae

- Soft-bodied

- Preserve

A Source of Common Confusion

in alcohol
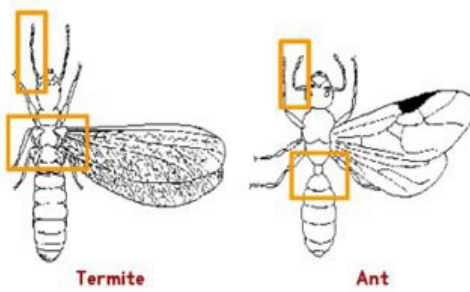

- Ants

- Order Hymenoptera

- Waist

- Forewing larger than hindwing

- Geniculate (elbowed) antennae

all - Hard exoskeleton

Figure 6. The characteristics that separate swarming termites from swarming ants. Most people can see the waist on an ant.

Credits: Jane Medley, UF/IFAS

distribution map for Florida: https://flrec.ifas.ufl.edu/ termites-in-florida/termite-distribution/. They are in the process of collecting information from other states.

Many states offer identification services through Extension. Fees are usually nominal compared to the cost of damage to your home. Click on your state at this link to begin the search: https://nifa.usda.gov/ land-grant-colleges-and-universities-partner-websitedirectory? state $=$ All\&type $=$ Extension

Some known insect identification clinics:

Auburn University: https://enpp.auburn.edu/outreach/ plant-diagnostic-laboratory/

North Carolina State University: https://projects.ncsu.edu/ cals/plantpath/extension/clinic/

Texas A\&M: https://citybugs.tamu.edu/idhelp/

University of California, Riverside: https://entomology.ucr. edu/diagnostics-and-identification

\section{UF/IFAS Insect ID Lab: http://entnemdept.ufl.edu/insectid/}

University of Georgia: https://ugaurbanag.com/ uga-insect-identification-services/

University of New Hampshire: https://extension.unh.edu/ programs/insect-identification-services

Virginia Tech: https://www.insectid.ento.vt.edu/ 


\section{HOW TO SUBMIT A TERMITE SAMPLE FOR IDENTIFICATION}

If you plan to submit termites for identification, please place as many termites as you can collect in a small, tightly sealed container of hand sanitizer or rubbing alcohol $(70 \%$ isopropyl alcohol) (Figure 7). The winged swarmers and soldiers are best for identification. Workers are the most numerous in the colony but the most difficult to use in identification.

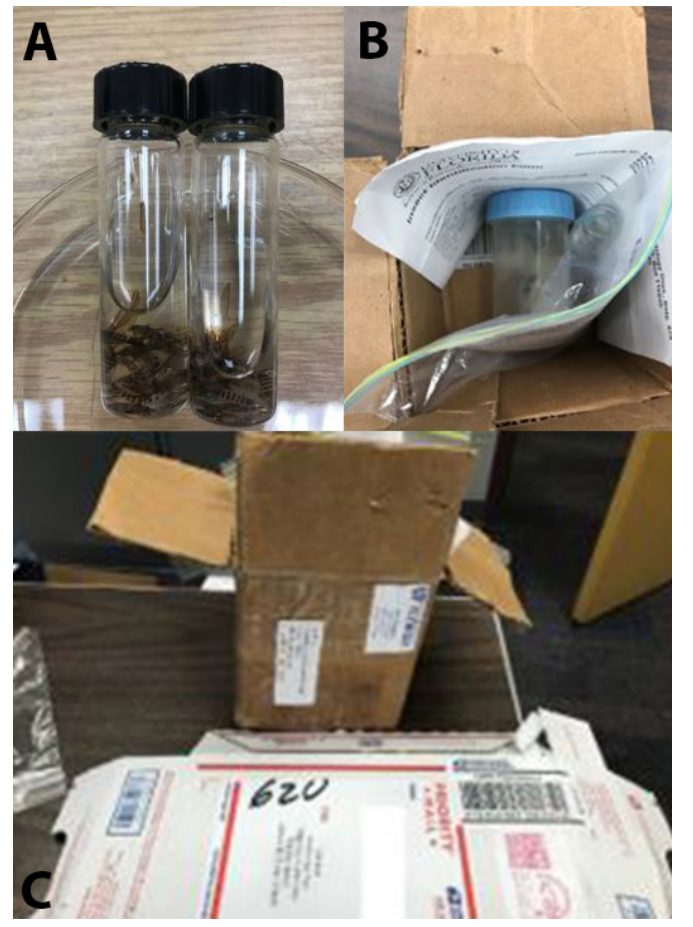

Figure 7. a) Place termite sample in a vial with hand sanitizer or rubbing alcohol. Make sure the vial does not leak. b) Place samples in box that will protect leakproof vials or containers. c) Boxes can be of all shapes and sizes, as long as they protect the sample.

Credits: Faith Oi, UF/IFAS

Do not mail termites in a plastic bag placed in an envelope because important characteristics are crushed during delivery (Figure 8). If you plan to mail the sample, place the container in a box.

Please include the following information: Name, how best to contact you (e.g., email, phone number) date, location (address) collected, where collected (i.e., inside or outside home, door or window framing, wooden studs, etc.). Some insect identification laboratories have fillable forms with questions that can aid in identification. See example: http:// edis.ifas.ufl.edu/pdffiles/SR/SR02200.pdf

Submitting pictures of termite damage can be helpful, but generally insect identification requires a sample of the actual insect. The vast majority of photographs submitted do not include the characteristics needed for identification and are not clear enough.

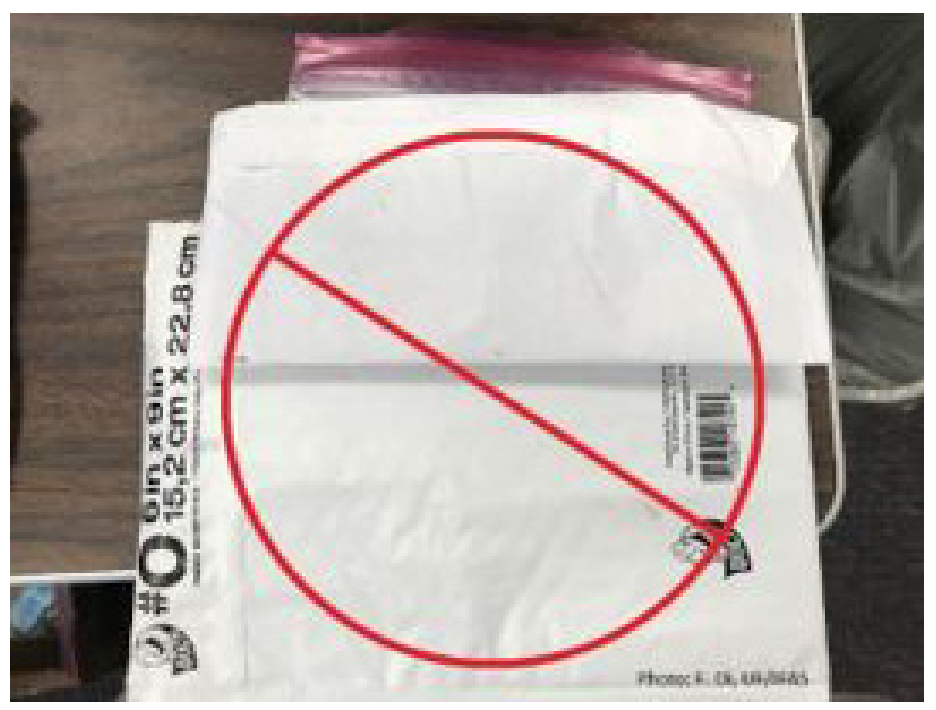

Figure 8. Do not mail samples in envelopes, even padded envelopes. Samples mailed in envelopes often arrive crushed.

\section{Termite Prevention}

Homeowners can help prevent termite infestations by implementing good home maintenance practices. Keys to termite prevention include minimizing moisture, minimizing food sources, and making your home easier to inspect. Examples:

- Eliminate wood-to-ground contact (Figure 9).

- Remove wooden debris such as lumber and branches from property.

- Stack firewood away from your home or any structure you want to protect.

- Keep an inspection space of at least 6 inches from the bottom of wall sidings and the soil or mulch line (Figure 10).

- Inspection spaces allow termite tubes to be detected (Figure 11).

- Ensure that water runs from the structure, not toward it.

- Direct A/C drainage lines away from your house.

- Fix leaks.

- Direct irrigation heads away from walls (Figure 12).

- Install gutters to manage the flow of water away from your home (Figure 13).

- Do not place or store items like rain barrels, compost bins, or other items that hold moisture at ground level within 2 feet of the foundation of your home.

- Place landscape plants at least 2 feet away from exterior walls (Figure 14).

- Account for future growth. 


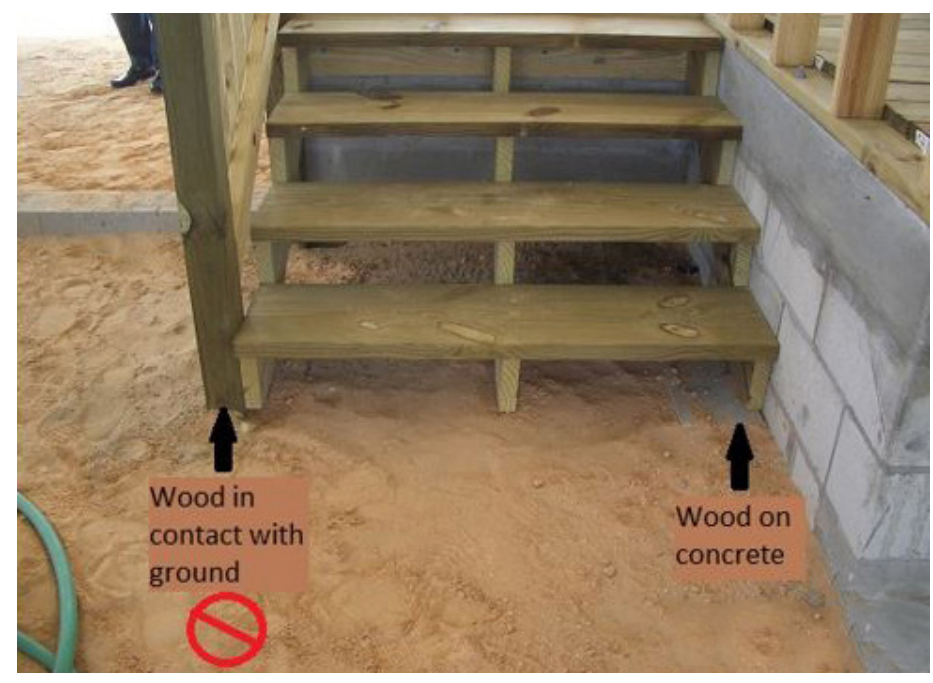

Figure 9. Example of wood-to-ground contact. Other examples in homes that may have wood-to-ground contact include piers, posts, attached fences, and decks. In this picture, the part of the wooden stair that is on the concrete pad may gain slightly more protection, but termites can still find the stairs via the gap against the wall. Credits: Faith Oi, UF/IFAS

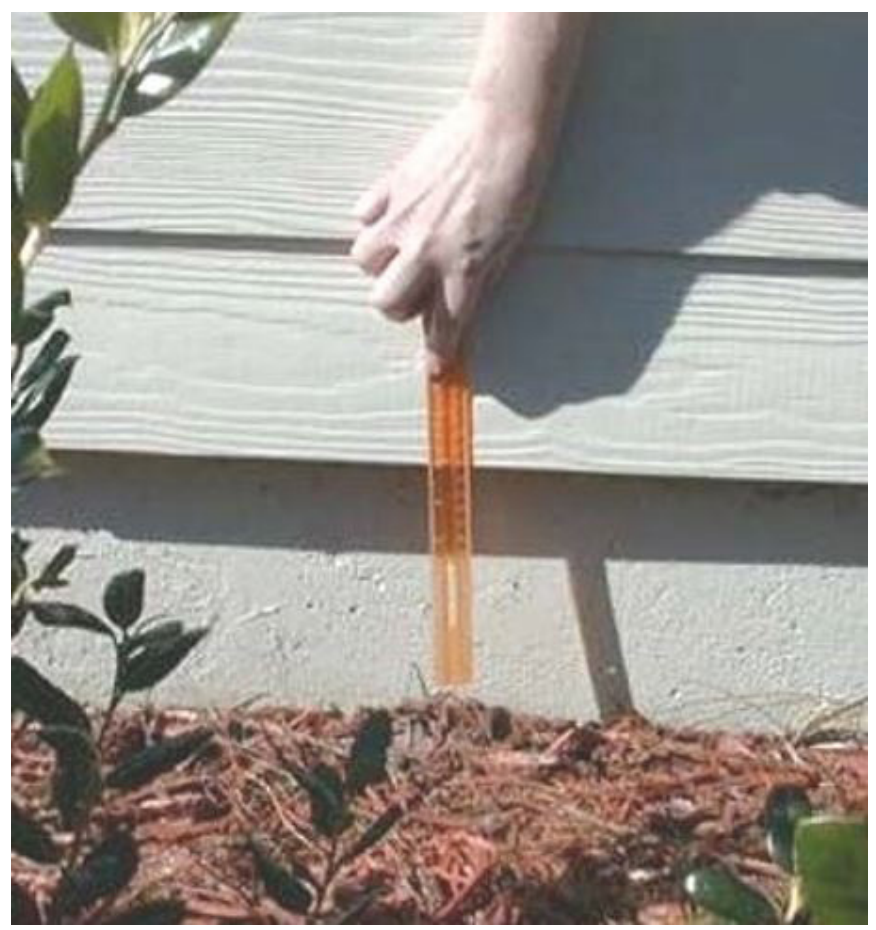

Figure 10. Building codes in many states require at least a 6-inch inspection space at the time of construction. It is important to maintain this inspection space and not hide it with mulch. When inspection spaces are obscured by mulch or other landscape plants, subterranean termites can access structures.

Credits: Faith Oi, UF/IFAS

- Remember that improper plant placement will create conditions attractive to termites, and that may void your termite warranty (Figure 15).

- Avoid using wooden landscape timbers for edging.

- Keep soffits in good repair and screen vents to help prevent termite swarmers and other pests from entering

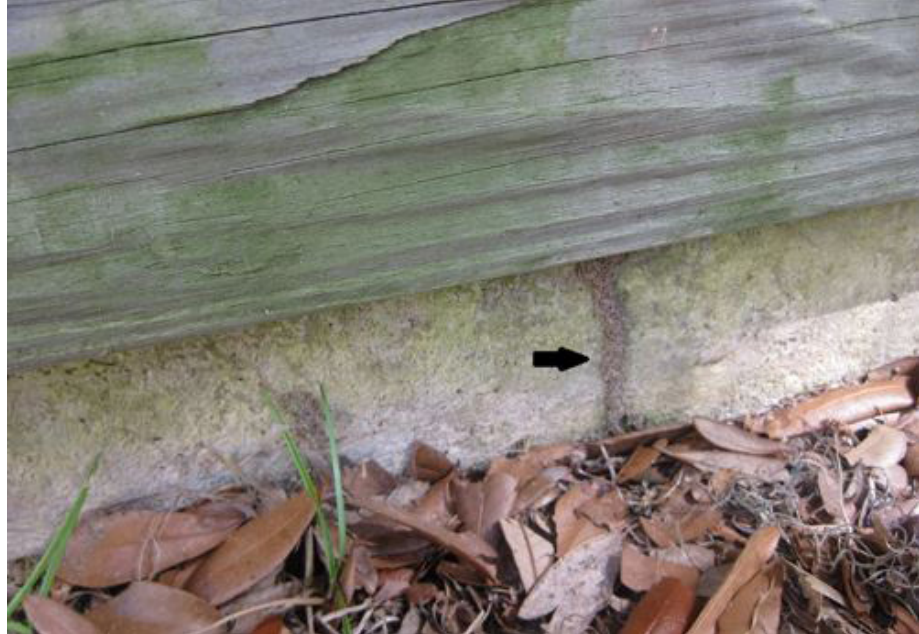

Figure 11. Termite tube that was detected on outside foundation wall that had an inspection space.

Credits: Faith Oi, UF/IFAS

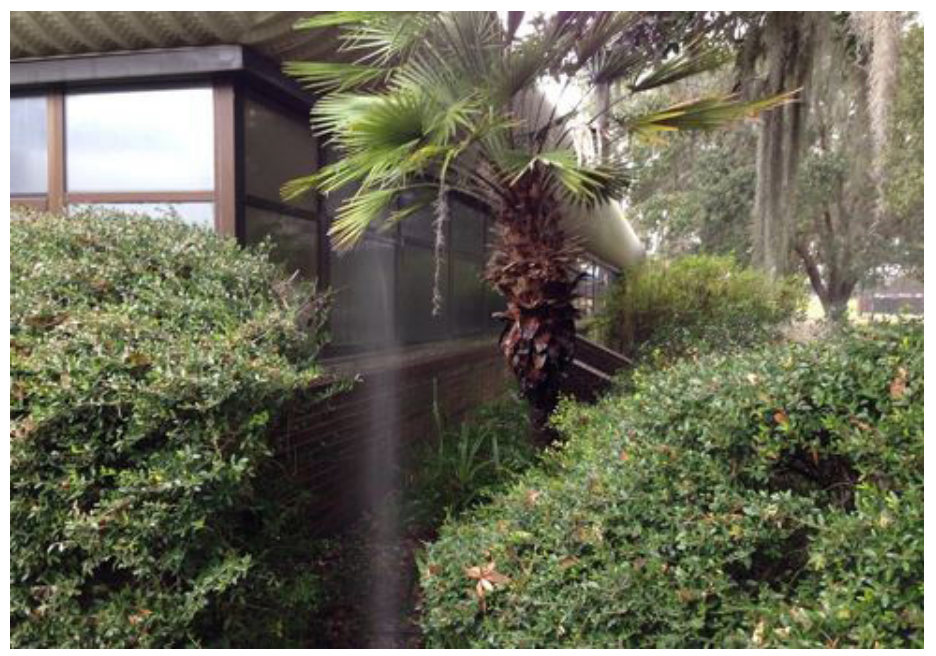

Figure 12. Irrigation head improperly directed, resulting in walls being watered. Wet walls create a conducive condition that will allow termites to thrive.

Credits: Faith Oi, UF/IFAS

attics. Drywood termites more commonly infest soffit and attic areas.

- Trim tree and shrub branches away from walls and roofs (Figure 16).

- Branches must not touch the roof of a structure. Subterranean termites can use branches as bridges to access structures (Figure 17)

- Consider contracting the services of a pest control company with experience and certifications in termite control to do an "annual renewal inspection."

- An annual renewal inspection is an inspection that is done on a year-to-year basis by someone who should be trained in how to recognize evidence of termites and potential problems. 


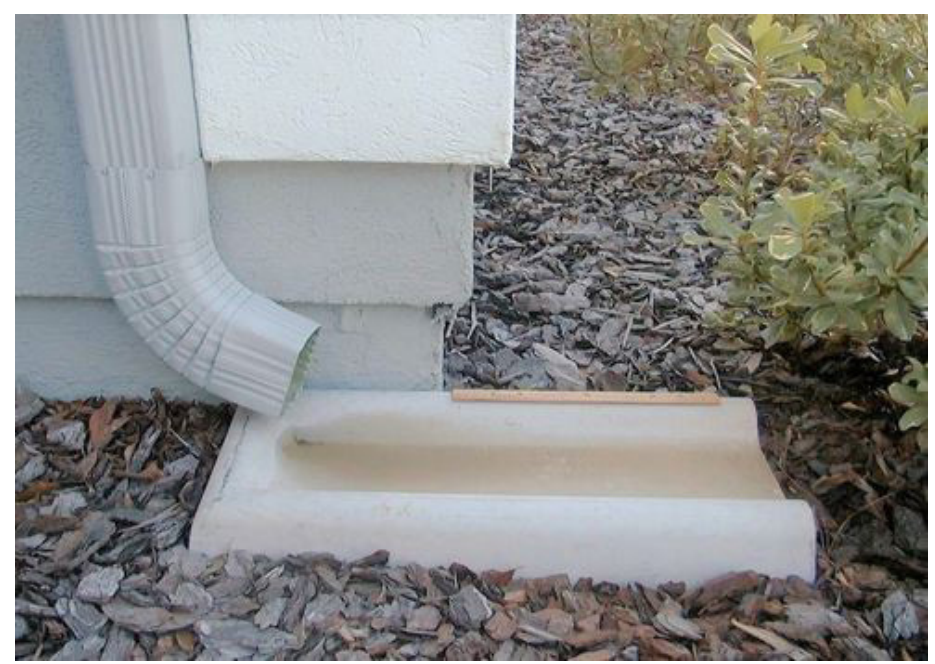

Figure 13. Splash block to divert water from gutter away from home. Credits: Faith Oi, UF/IFAS

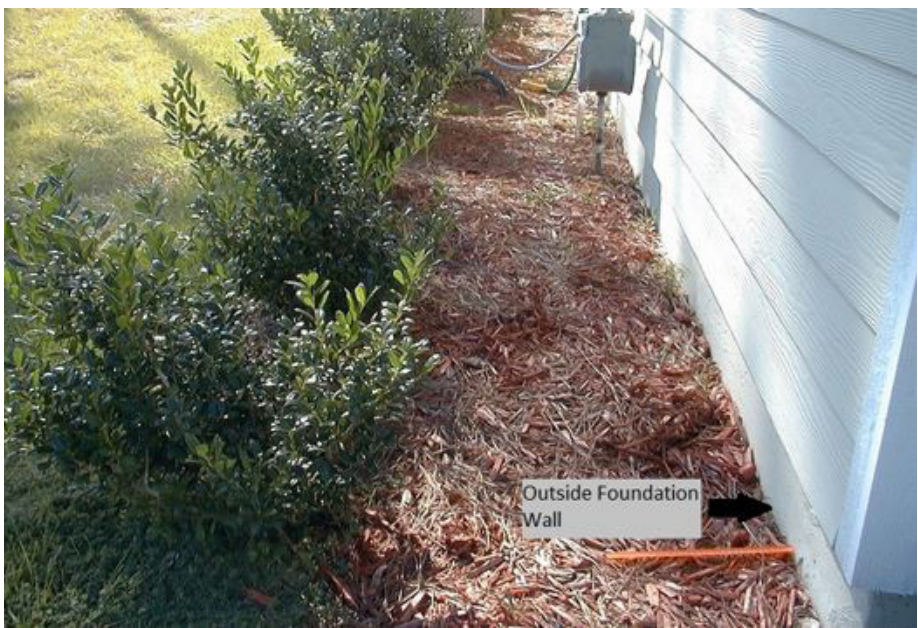

Figure 14. This home has maintained an excellent inspection space between the siding and mulch. Landscape plants are also positioned far enough away from the outside foundation wall to decrease moisture close to the home, and the placement accounts for future growth. Moisture is a conducive condition that can void some termite warranties.

Credits: Faith Oi, UF/IFAS

- Some states require additional training to do these types of inspections with proof of training recorded on identification cards.

- Some states separate the annual renewal inspection from an inspection for the purposes of a real estate transaction.

\section{Details of Termite Types, Evidence of Infestation, and Termite Control Methods}

This section is designed to help you determine what type of termite you have and control options to consider. Table 1 in the section titled "Summary of Termite Types and Methods of Control," above, summarizes control options for common wood-destroying organisms. Termite prevention
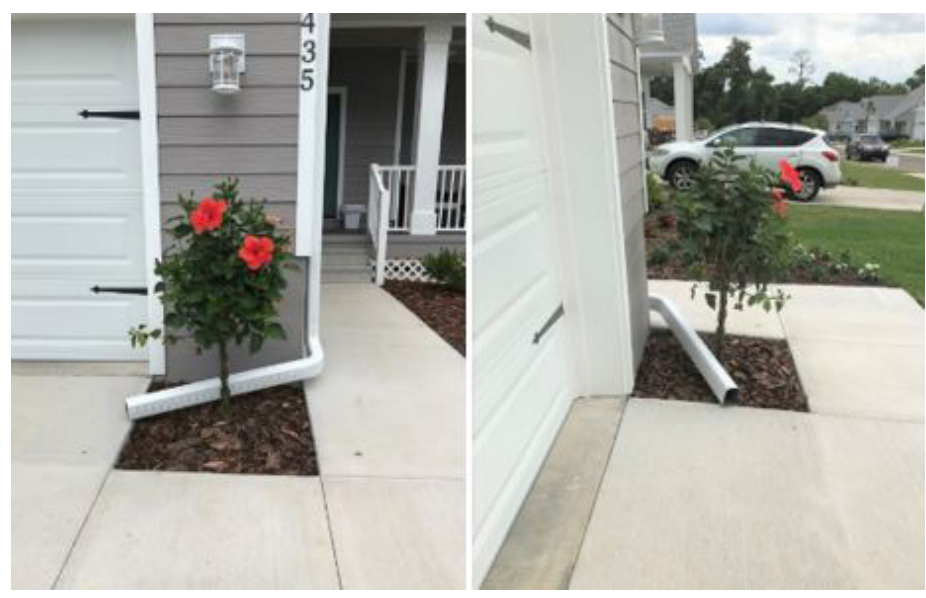

Figure 15. Improper plant placement and poor gutter placement. This newly planted hibiscus is one foot away from the home, but the branches are already almost touching the wall. Credits: Faith Oi, UF/IFAS

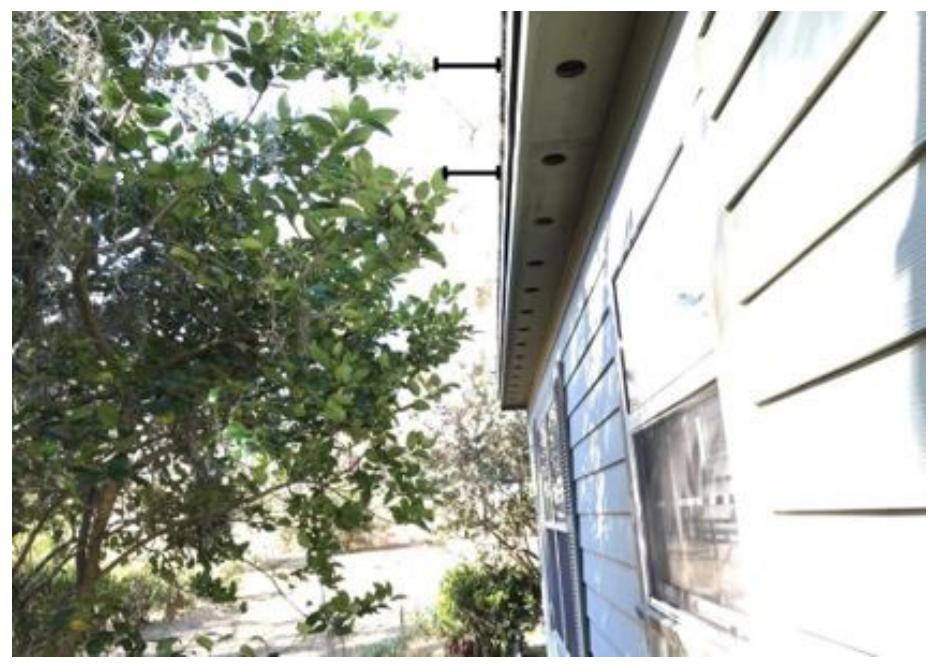

Figure 16. YES! Branches are cut away from the home to eliminate access.

Credits: Faith Oi, UF/IFAS

includes an annual inspection by a pest-management professional trained in the identification and control of termites and other wood-destroying organisms.

\section{Dampwood Termites}

- Require a wet (i.e., free water) environment. Often found in trees.

- Signs of dampwood termites: mix of loose and clumped pellets (Figure 18). Examples of damage (Figure 19) and live dampwood termites (Figure 20) in pictures below.

- Control: Drying the infested area is usually enough to control dampwoods. Drying may entail fixing roof and water leaks if the wood is not too decomposed. Wood replacement and moisture prevention are effective. It is possible to use borate-containing products such as BoraCare ${ }^{\circledast}$ because the moisture in the wood will enhance the penetration of the product. Caution: Borates are toxic to plants. Do not use on live plants. 


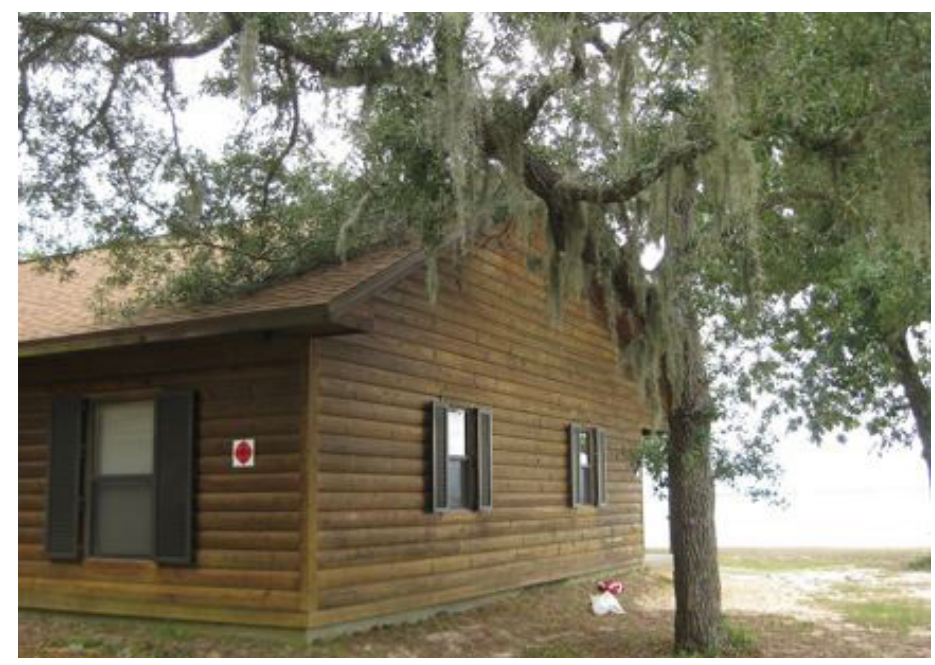

Figure 17. NO! The branches resting on the roof of this structure likely provided access for the Formosan subterranean termites that were found infesting the room below them.

Credits: Faith Oi, UF/IFAS

- Zootermopsis spp. are found in the Pacific Northwest. Neotermes spp. can be found in Florida and coastal southwestern states.

- More information on the Florida dampwood termite: http://entnemdept.ufl.edu/creatures/urban/termites/ neotermes.html

\section{Drywood Termites}

Infestations are usually localized and in sound wood. Drywood termite colonies are not connected to the ground, so their galleries do not have mud in them (Figure 21). Colonies are often contained in a single piece of wood because colonies tend to remain relatively small. Galleries are smooth, going across the grain of the wood, and can extend for several feet. Evidence includes 6-sided pellets (Figure 22) that are pushed out of the colony through kickholes that are about the size of a pen tip (Figure 23). Pest control professionals often describe frass as "sand-like" particles. They also describe swarmer wings as being "iridescent" in color. Some drywood termites have soldiers with heads that are sometimes referred to as looking like a burnt matchstick. This is called a phragmotic head (Figure 24). Comprehensive information on drywood termites and their control can be found here: http://ipm.ucanr.edu/ PMG/PESTNOTES/pn7440.html.

The most common control methods for drywood termites:

- Replace infested wood, usually if limited to door or window trim.

- Remove infested furniture or other items having termite damage

- Spot treat with products labeled for drywood termites.

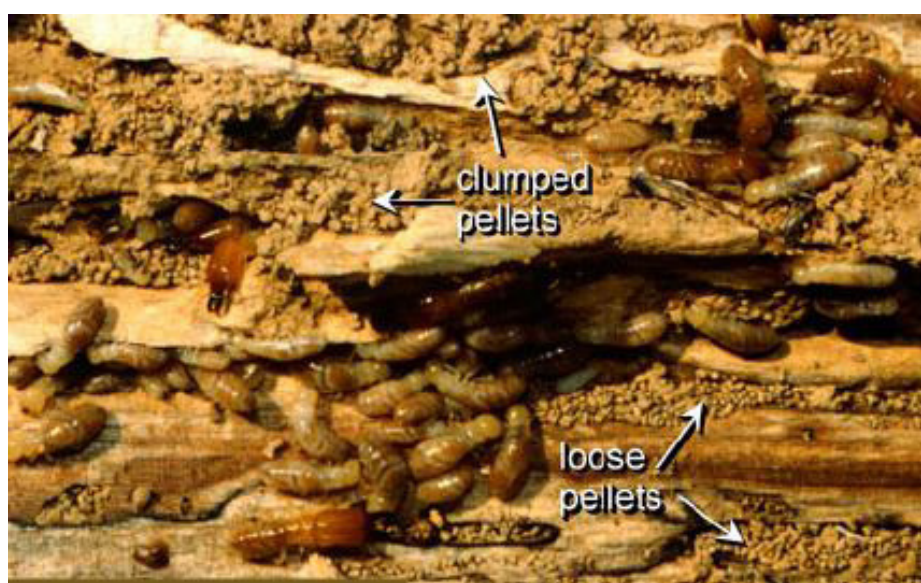

Figure 18. Evidence of dampwood termites includes a mix of clumped and loose fecal pellets.

Credits: Rudolf H. Scheffrahn, UF/IFAS

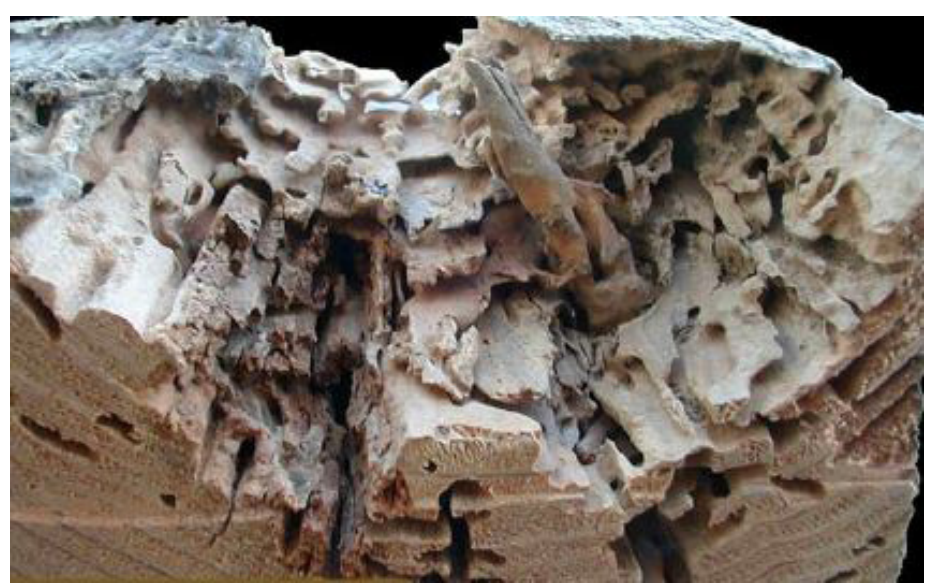

Figure 19. Neotermes jouteli (Banks) damage in 4-inch $\times 8$-inch beam removed from a house in Ft. Lauderdale.

Credits: Rudolf H. Scheffrahn, UF/IFAS

- Requires thorough inspection to find drywood termites for spot treatments to be successful.

- Fumigation (Figure 25).

- Is highly effective. Fumigation essentially kills everything in the structure and is a "reset button" for drywood termites.

- Fumigation is heavily regulated.

- Requires products that are designated as "restricted use."

- California and Florida do the most fumigations in the country.

- The Florida Department of Agriculture and Consumer Services has developed a helpful list of frequently asked questions. Most are applicable across the United States:

- https://www.freshfromflorida.com/Consumer-

Resources/Health-and-Safety/Protect-Your-Homefrom-Pests/Florida-Structural-Fumigation-Information/ Structural-Fumigation-FAQ 


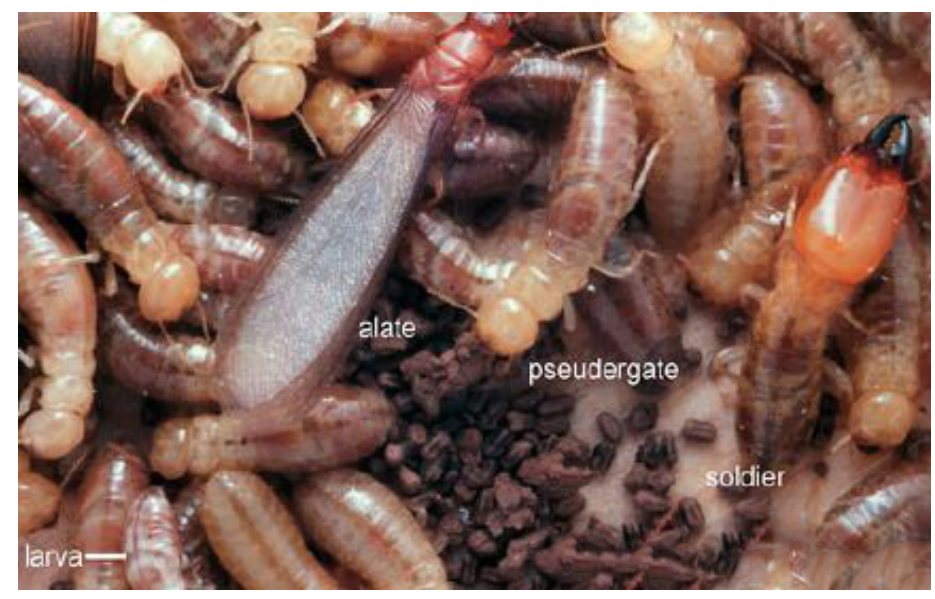

Figure 20. Castes in a Neotermes castaneus (Burmeister) colony. Credits: Rudolf H. Scheffrahn, UF/IFAS

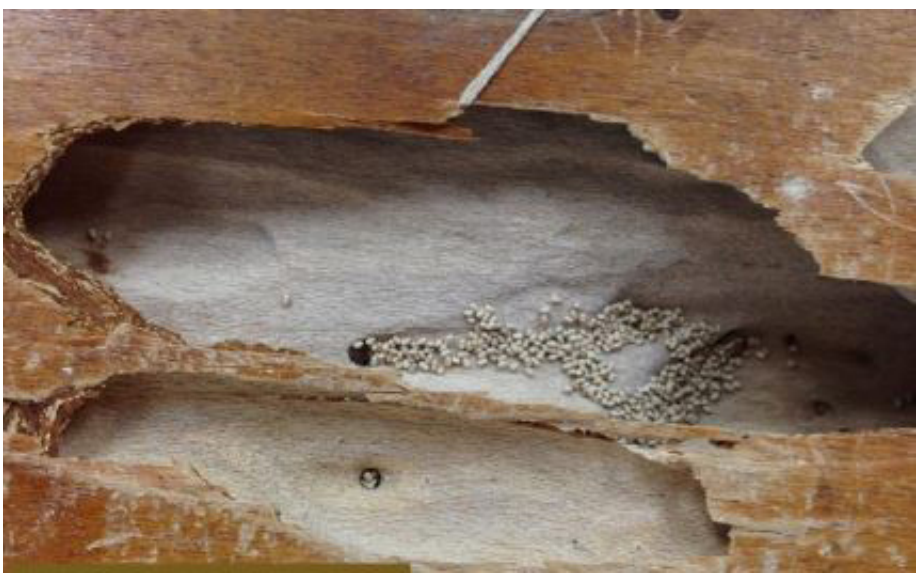

Figure 21. Drywood termite galleries are smooth, going across the grain of the wood, and can be several feet long.

Credits: Faith Oi, UF/IFAS

\section{Subterranean Termites}

Subterranean termites usually reside in the ground. One of the reasons that subterranean termites are particularly difficult to control is because colony size on average is from a few thousand to several million, covering from a few square feet to over an acre. One study from North Carolina reported that there can be 25 colonies of native subterranean termites per acre of land (Parman et al. 2003). In other studies, Formosan subterranean termite colonies covered between 1 to 1.5 acres. Thus, it is possible to build your home on an entire colony.

Description (Figure 26): Workers are cream colored. They are the damaging form. Soldiers have a darker head with mandibles that protrude forward. Swarmers have wings and can be honey-colored to black, depending on species. Swarming termites emerge during the spring. Sometimes there is a second, smaller swarm during the fall.

Subterranean termites use mud tubes to travel above ground. Mud tubes consist of soil, subterranean termite

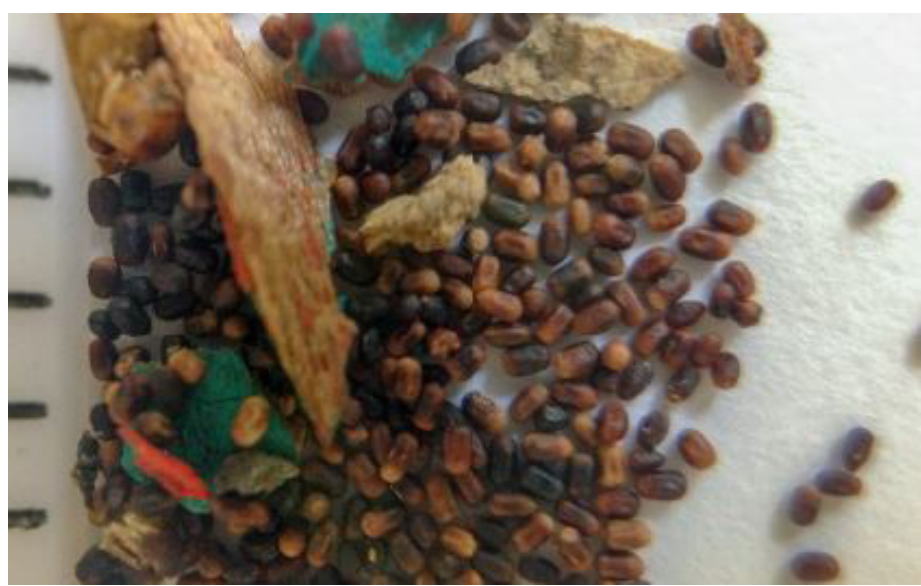

Figure 22. Evidence of drywood termites include six-sided fecal pellets using $20 \times$ smartphone magnifier.

Credits: Faith Oi, UF/IFAS

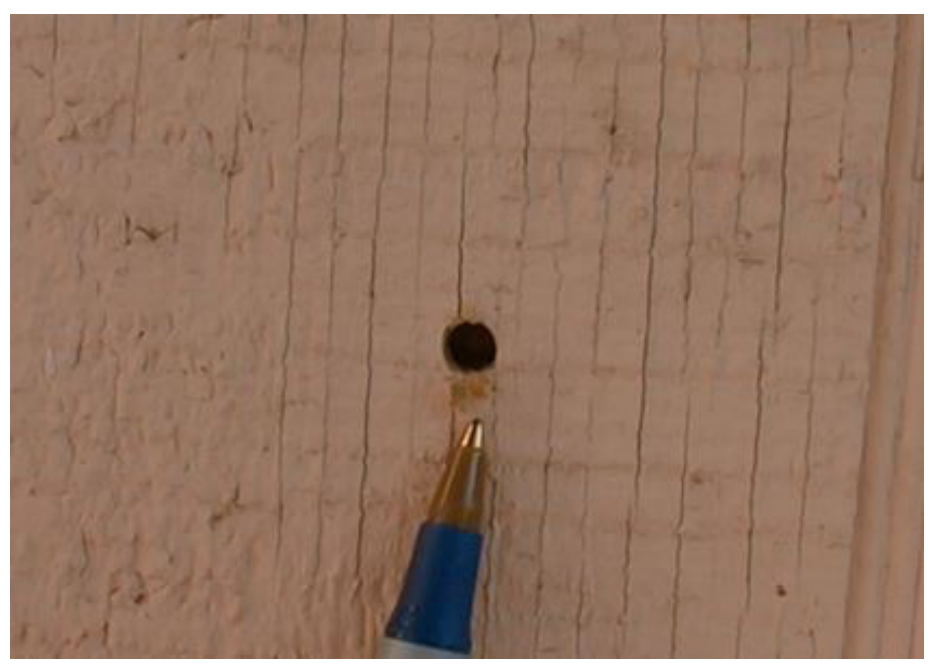

Figure 23. Drywood termite "kickhole." Credits: Faith Oi, UF/IFAS

feces, and partially digested wood. Tubes are strong evidence for subterranean termites. They protect termites from desiccation and possibly predators (Figure 27 ). Subterranean termites cause feeding damage with the grain of the wood (Figure 28), sometimes only leaving a thin veneer of undamaged wood at the surface, which is why you may see a termite inspector probing and tapping (Figure 29) the surface of baseboard, door frames, and other areas that are common subterranean termite entry points (Figure 30). Subterranean termites can cause serious damage to structural elements, such as 2 by 4 s (Figure $31 \mathrm{a}$ and $\mathrm{b}$ ).

\section{SPECIAL REFERENCE TO FORMOSAN SUBTERRANEAN TERMITES}

Formosan subterranean termites are an invasive species that is spreading through the United States. This species is in the top 100 species on the global invasive species list (Global Invasive Species Database 2019, http://www.iucngisd.org/ gisd/100_worst.php). The closely related Asian subterranean termite is also spreading. Treatment will be similar 


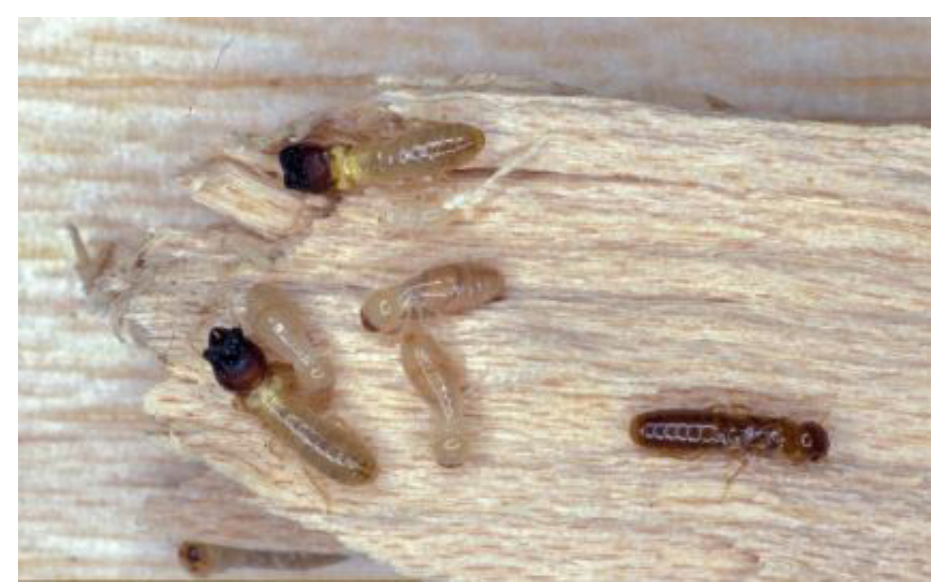

Figure 24. Example of live drywood termites. These termites are, commonly found in furniture. Worker is completely cream-colored; soldier with "burnt matchstick" like head (phragmotic); adult is darker brown.

Credits: J. Castner, UF/IFAS

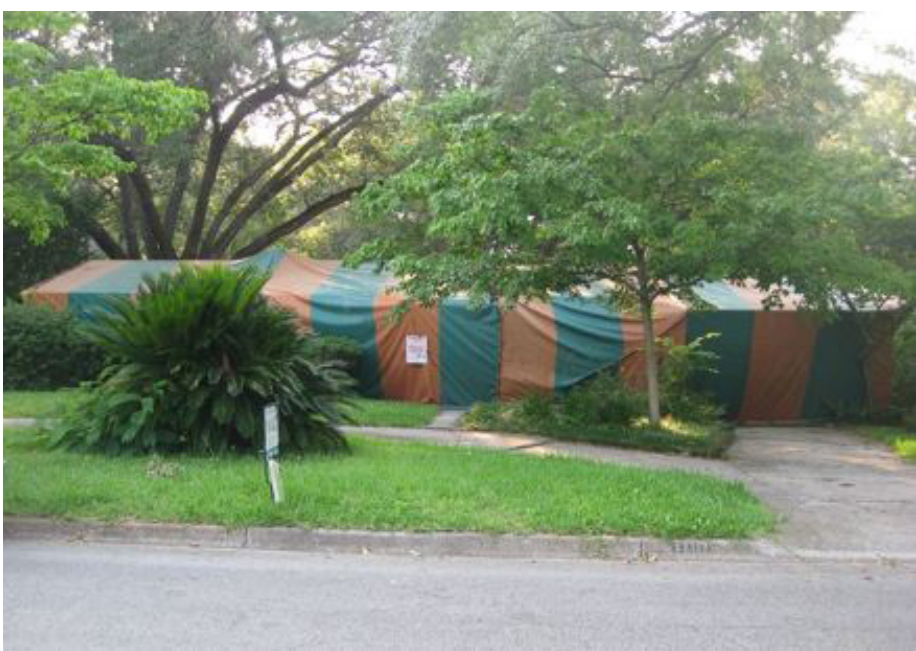

Figure 25. Fumigation is highly effective against drywood termites. Structures are tented and tightly sealed to hold the fumigant (active ingredient: sulfuryl fluoride). It is critical that no one enter the structure because he gas is highly toxic. Once properly aerated and cleared using sensitive instrumentation, the home can be entered again.

Credits: Faith Oi, UF/IFAS

to other subterranean termites, but pest control contracts may be written differently if your home is infested with this species. Some states, like Florida, will allow companies to exclude Formosan and Asian subterranean termites from contract warranties. Read your contracts carefully.

These termites notoriously infest trees (Figures 32 and 33). If you find these termites in trees, call an experienced pest control company to treat them. You may see the pest control company foam the voids with a registered termiticide, place baits at the base of the tree, or use an "aboveground" version of bait that is secured to the tree where Formosan subterranean termites are found. Soil drenches with systemic insecticides labeled for applications may also be used.

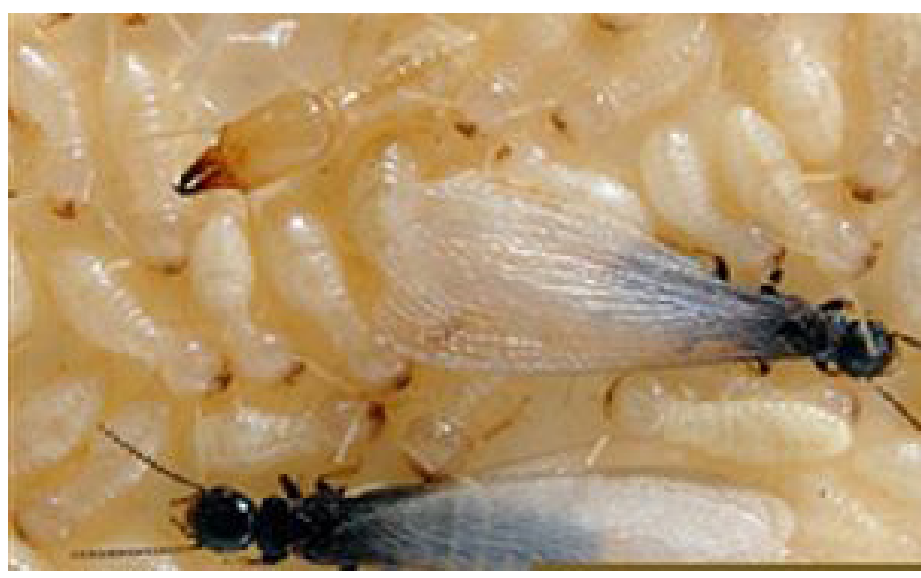

Figure 26. Subterranean termite workers, soldier (darkened head) and alates with wings. Reticulitermes spp.

Credits: Rudolf H. Scheffrahn, UF/IFAS

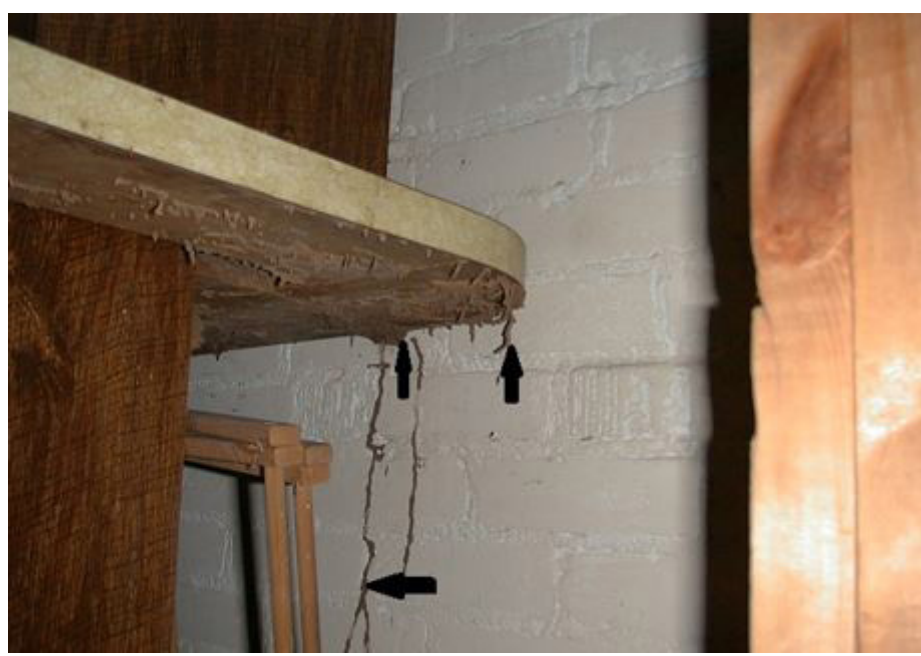

Figure 27. Subterranean termite mud tubes on wall and under countertop.

Credits: Faith Oi, UF/IFAS

A myth that still circulates in popular media is that Formosan subterranean termites can "melt concrete" with "acid that shoots from the front of their head." This story is simply not true. The termite does have a structure on its head that exudes a substance, but the substance is not rockdissolving acid. They secrete a kind of latex that defends them against arthropods about their size.

\section{Additional resources on the Formosan subterranean termite:}

\section{- Identification of the Formosan Subterranean Termite}

Google "UGA Formosan subterranean termites" or use this link https://secure.caes.uga.edu/extension/publications/ files/pdf/C\%20868_4.PDF

- National Invasive Species Information Center: https://www.invasivespeciesinfo.gov/profile/ formosan-subterranean-termite 

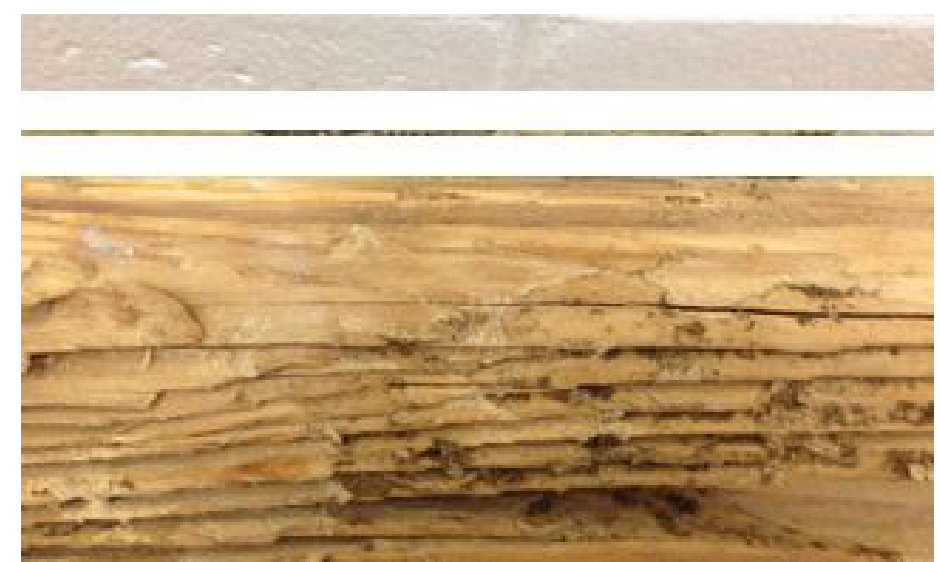

Figure 28. Subterranean termite feeding damage along the grain of the wood.

Credits: Faith Oi, UF/IFAS

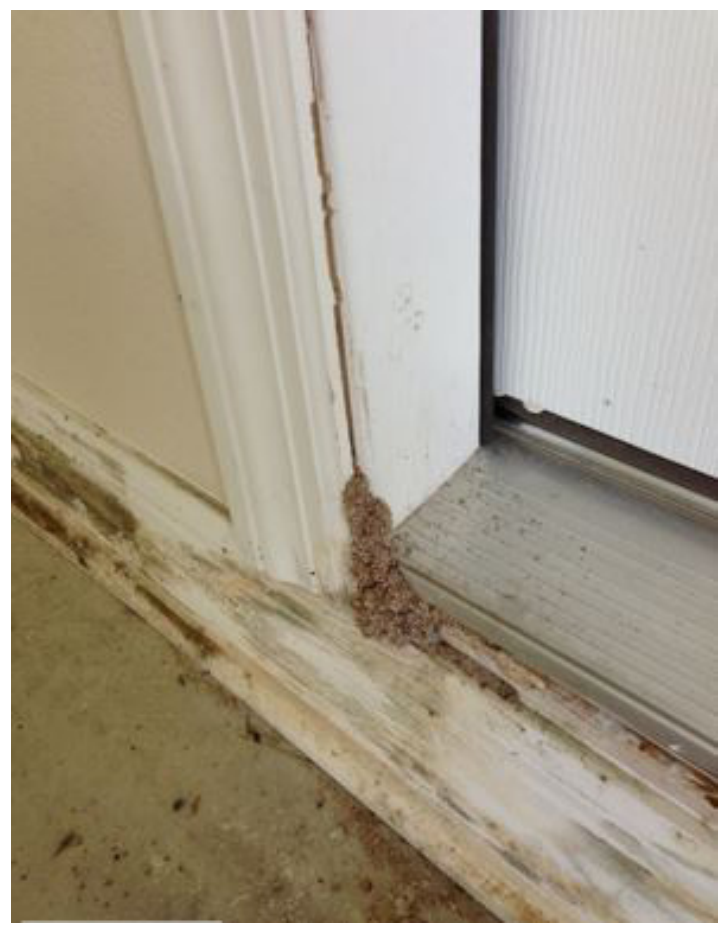

Figure 30. Subterranean termite mud tube at garage door baseboard and door frame, a common entry point.

Credits: Faith Oi, UF/IFAS

- Formosan Subterranean Termite Program, Florida. https://www.freshfromflorida.com/Consumer-Resources/ Health-and-Safety/Protect-Your-Home-from-Pests/ Termites/Formosan-Termite-Program . Comprehensive list of links, including to the University of Florida and University of Georgia resources. FDACS Formosan project contact: Johanna Welch, DPM, Johanna.Welch@ FreshFromFlorida.com

- UF/IFAS Subterranean Termite Research website: https:// flrec.ifas.ufl.edu/termites-in-florida/

- Related species, Asian subterranean termite: http:// entnemdept.ufl.edu/creatures/urban/termites/havilandi. htm

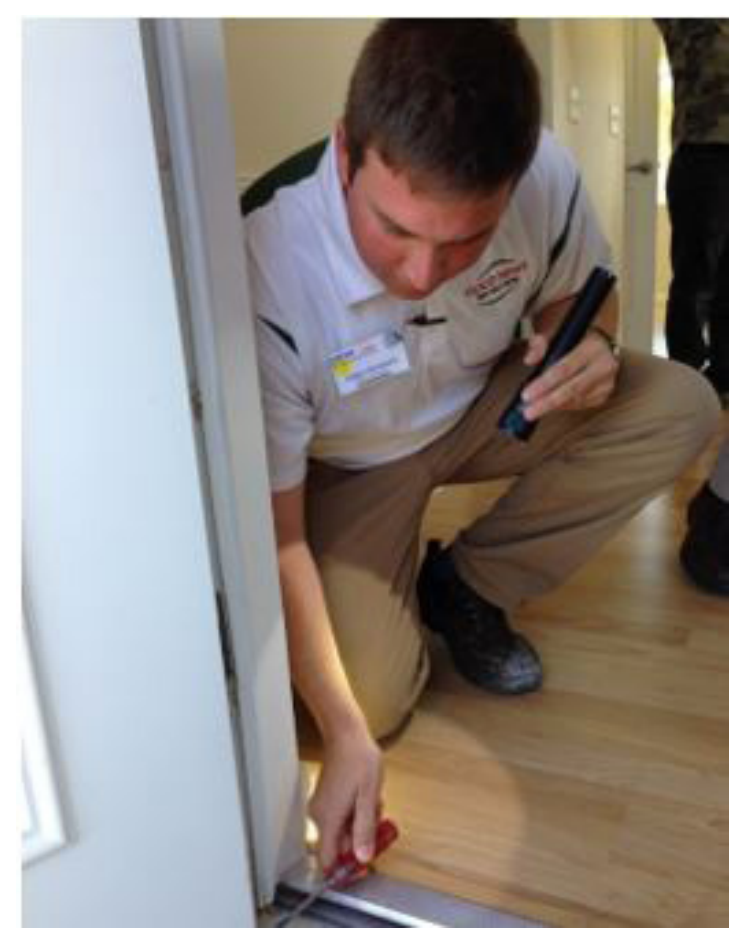

Figure 29. Probing and sounding door frame and door threshold during termite inspection exercise at UF/IFAS Extension program, Pest Management University.

Credits: Faith Oi, UF/IFAS

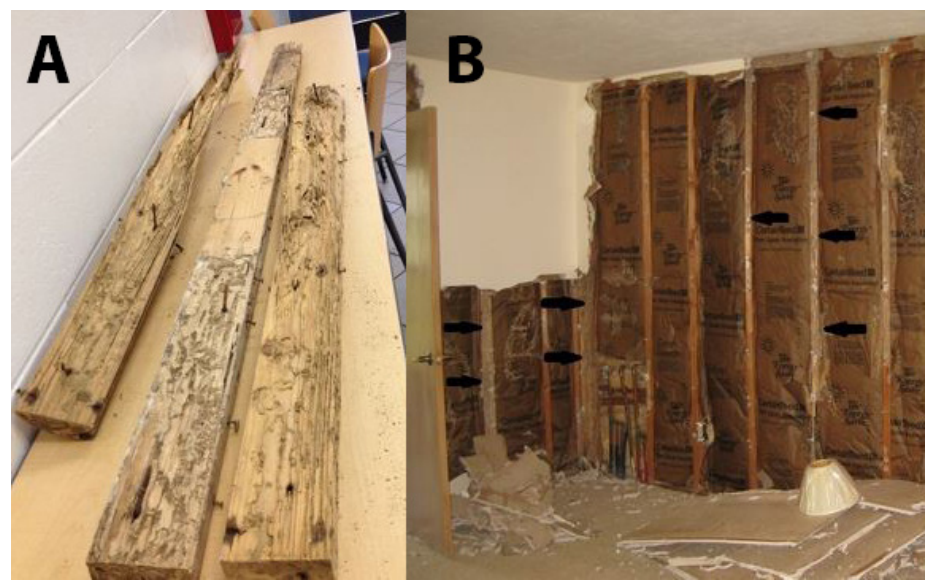

Figure 31. A) Subterranean termite damage in a room; B) Termites are blind, soft-bodied insects, so they follow guidelines, including wall studs. Arrows denote areas of prominent mud tubes.

Credits: Faith Oi, UF/IFAS

- North Carolina State University, Formosan Termite in North Carolina and 2018 Update: https://content.ces. ncsu.edu/formosan-termites-in-north-carolina

- Texas Agrilife Extension:

- https://urbanentomology.tamu.edu/urban-pests/termites/ formosan/

- https://agrilife.org/extensionento/publications/ formosan-subterranean-termites/ 


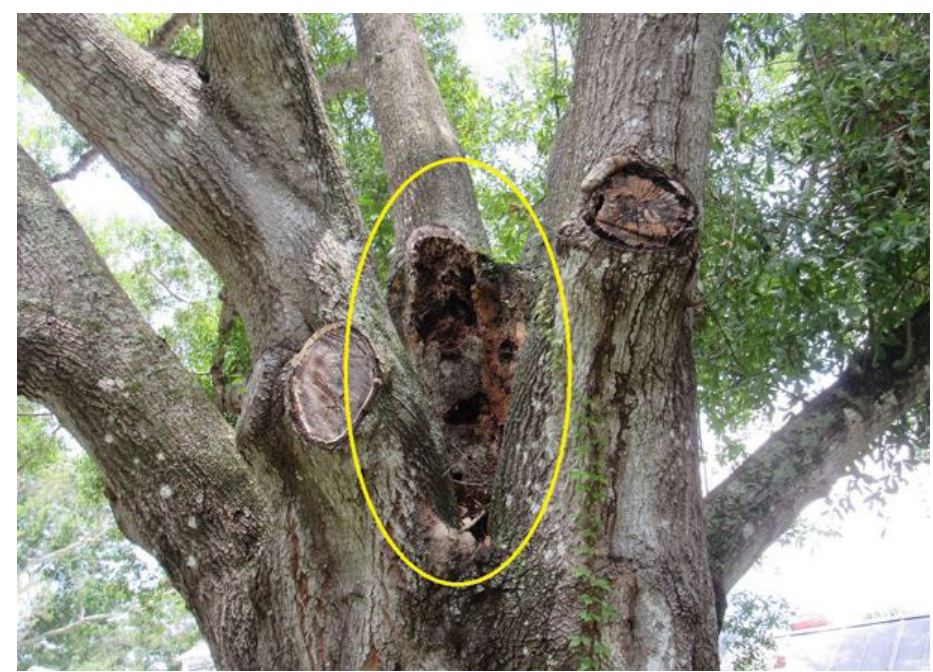

Figure 32. Tree damaged by Formosan subterranean termites. Cavity filled with mud and carton material.

Credits: Faith Oi, UF/IFAS

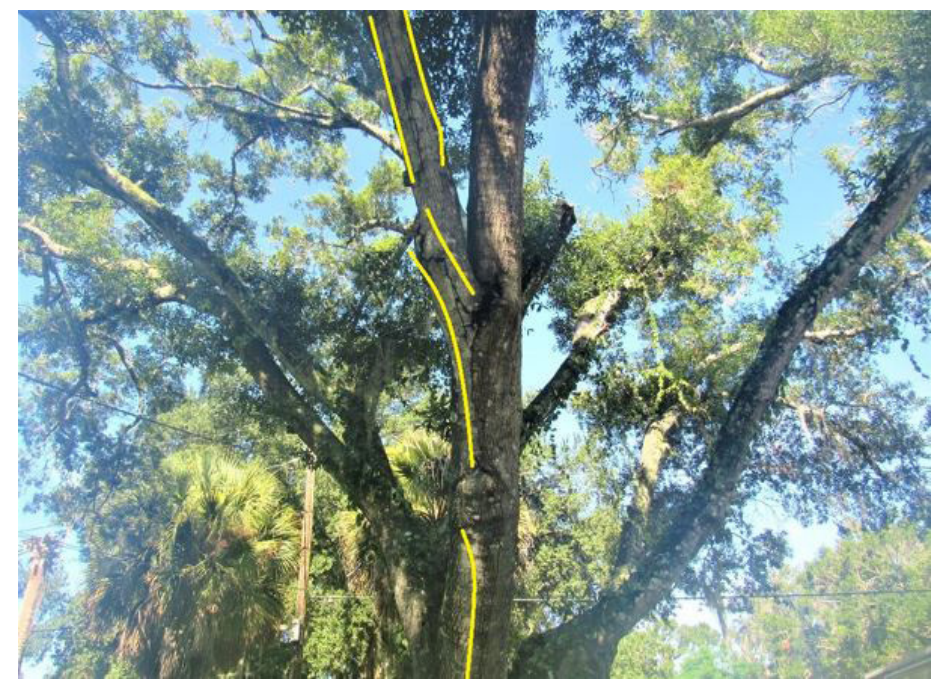

Figure 33. Formosan subterranean termite mud tubes on tree, highlighted in yellow.

Credits: Faith Oi, UF/IFAS

\section{SUMMARY OF BEST MANAGEMENT PRACTICES FOR SUBTERRANEAN TERMITE PREVENTION INCLUDE:}

- Schedule regular inspections by someone trained in inspecting for termites.

- Move items out from the garage and other storage areas periodically and look for mud tubes.

- Follow good building construction practices.

- Avoid wood-to-ground contact.

- Avoid creating hidden access by burying exterior wall coverings with soil or mulch.

- Keep an inspection space that is at least 6 inches from the soil line to any exterior wall covering.
- Make sure that the slope of the land around your home allows water to flow away from your home, not toward it.

- Eliminate moisture and other conducive conditions. Do not plant vegetation close to outside foundation walls or direct irrigation toward walls.

- Eliminate debris and hidden access.

- Know where invasive termites have been found. Use the termite distribution map for Florida: https://flrec.ifas.ufl. edu/termites-in-florida/termite-distribution/

\section{COMMON METHODS OF SUBTERRANEAN TERMITE CONTROL:}

- There are two times that a home can be protected from subterranean termites.

- At the time of construction, often called "pre-construction" in the pest control industry.

- After construction, called "post-construction" or "remedial treatments" in the pest control industry.

- The methods of control are similar whether in the pre- or new construction phase or post-construction.

\section{Soil Termiticides}

- Application of liquid soil termiticides is still the most common method of termite control during pre-construction and post-construction. The amount of termiticide applied will vary by area to be treated, product label, and soil type.

- The applicator must have knowledge of building construction and equipment to apply the quantity of termiticide that may be required to treat your home.

- Sometimes drilling concrete slabs or concrete block walls is required.

- All soil termiticides registered by the Environmental Protection Agency (EPA) must meet performance standards in "Product Performance Test Guidelines OPPTS 810.3600 Structural Treatments" (https://www.regulations.gov/ document?D=EPA-HQ-OPPT-2009-0150-0009).

- In the pest control industry, you may hear of liquid termiticides falling into two (2) categories: repellent and non-repellent chemistries. Describing products in this way may not be technically accurate because at some point, as concentrations increase, any product can become "repellent." However, you may hear these terms when talking with pest management professionals.

- Examples of products that are "non-repellent" contain fipronil (Termidor ${ }^{\circledast}$, Taurus ${ }^{\circledast}$ ), imidacloprid (Premise ${ }^{\oplus}$, Dominion $^{\circledR}$ ), and chlorantraniliprole (Atriset $\left.{ }^{\oplus}\right)$. 
- Examples of products that are "repellent" contain bifenthrin (Bifen I/T ${ }^{\oplus}$, Talstar ${ }^{\circledR}$ ), permethrin (Dragnet ${ }^{\mathrm{Tx}} \mathrm{SFR}$ ).

How soil termiticides work: Termites can die either by contacting the soil termiticide or by ingesting treated soil during tunneling. Subterranean termites tend to enter soil treated with "non-repellent" termiticides more readily than soil treated with "repellent" termiticides, yet both types of termiticides eventually provide protection to the structure by acting as a barrier to termite colony foraging into and through the treated soil.

- The performance of soil termiticides over time is dependent on many factors, including putting out the correct amount, soil type, and environmental conditions.

- If the treated soil around your home is disturbed, for instance, by excavations for construction, digging by pets or wildlife, or a washing rain such as may be experienced during a hurricane, be aware that those areas may require another treatment.

- Soil termiticides do not generally kill entire colonies as can occur with some termite baits but can provide structural protection when applied properly and maintained.

\section{What You May See Your Pest Management Professional Do}

After pest management professionals inspect your home to determine where the subterranean termites are entering, you may see them:

1. Trench around the perimeter of your home (Figure 34) in preparation to treat around your home.

2. They may also drill the slab foundation to get the termiticide to areas that would otherwise be inaccessible (Figure $35 a$ and $b$ ).

3. Treating the trench (Figure 36) and drill holes.

\section{Baits}

- Termite baits have been approved by the Environmental Protection Agency (EPA) since the mid-1990s.

- Examples of EPA-registered baits are: Sentricon ${ }^{\oplus}$, which contains the active ingredient novaflumuron and Trelona ${ }^{\oplus}$, which contains the active ingredient novaluron.

- How baits work: Monitoring stations with cartridges containing a cellulose-based material containing an active ingredient are placed in the ground at regular intervals around a home in areas of known termite activity and where conducive conditions (i.e., there is plenty of moisture and/or access) occur. For baits to work, termites must find and feed on cellulosic material containing the toxicant.
- Termite colonies can be eliminated with baits. If there are no termites in the area of the home, the home is no longer at risk.

- The active ingredients in baits are in a class called "insect growth regulators" and delivered in a way that is specific to subterranean termites. These qualities place baits in an "environmentally friendly" category.

- Termite baits can be effective in homes that contain construction that is difficult to treat with liquid termiticides.

- Some states allow baits to be used in "new construction" instead of soil termiticides.

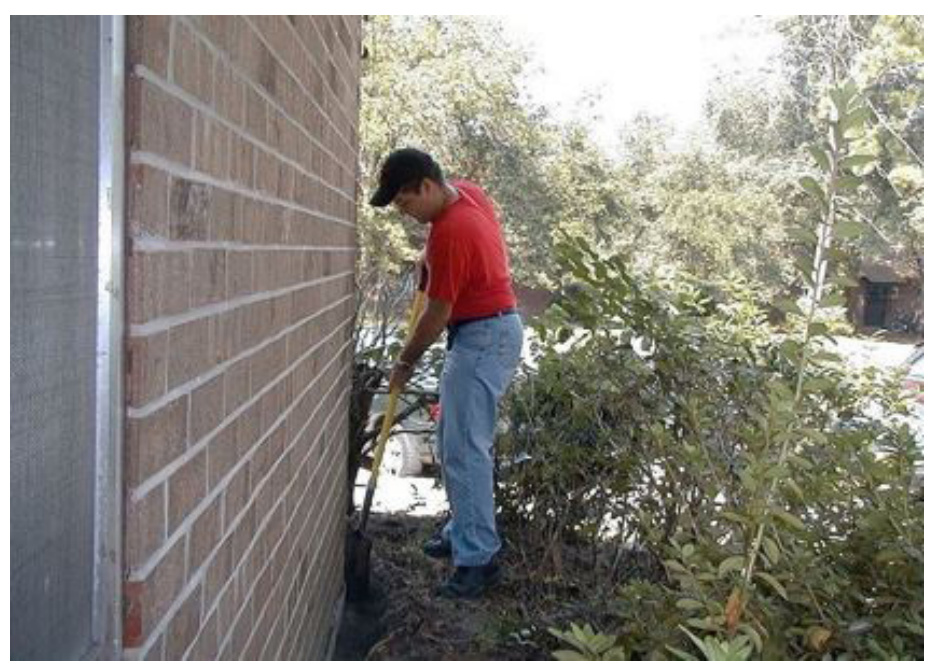

Figure 34. Trenching so that the termiticide can be applied into the trench according to the product label rate to cut off subterranean termite access from the outside.

Credits: Faith Oi, UF/IFAS

\section{Wood Treatments with Special Reference to Borates}

- Many termiticide labels allow treatment of wooden timbers as a part of termite control. However, borates present a special case of wood treatment because they can be used in new construction.

- Disodium octaborate tetrahydrate is a common active ingredient used in borate products to protect wood against termites and wood-decay fungi.

- Borate treatments for termites are usually only done during the new construction phase.

- Wooden timbers are sprayed with the borate solution and can remain stable for the life of the lumber when protected from weather.

- Examples of borate products are Bora-Care ${ }^{\circledast}$ and Tim-Bor .

- How it works: Termites must find the treated wooden members of your home and ingest a toxic dose. 


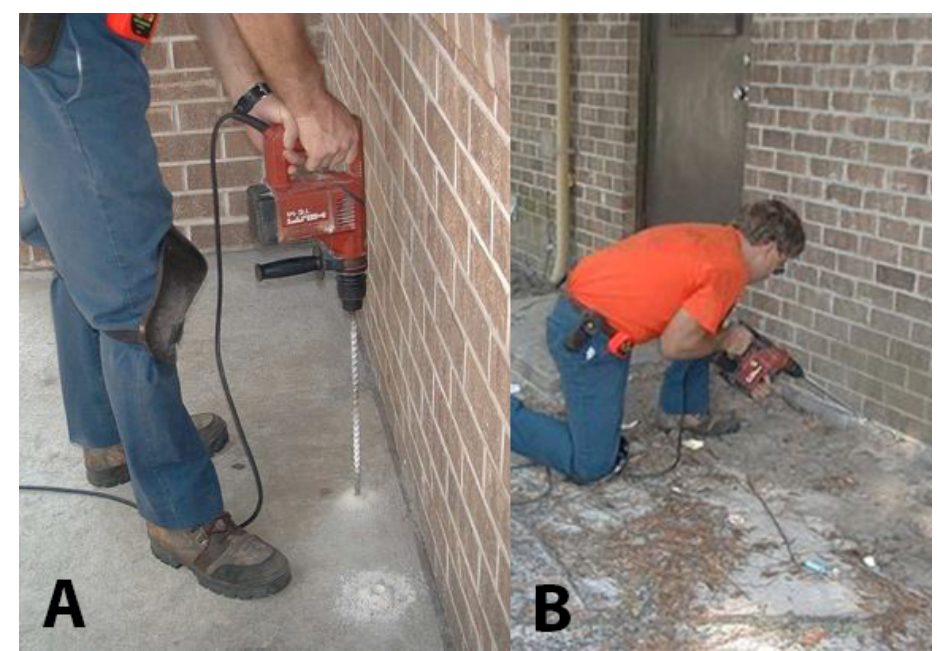

Figure 35. A) Down-drilling the slab so that termiticide can be injected under the slab and cut off subterranean termite access; B) Angle-drilling the slab. Another method to inject termiticide under the slab. Your pest management professional must understand building construction in order to know that the drill will emerge under the slab.

Credits: Faith Oi, UF/IFAS

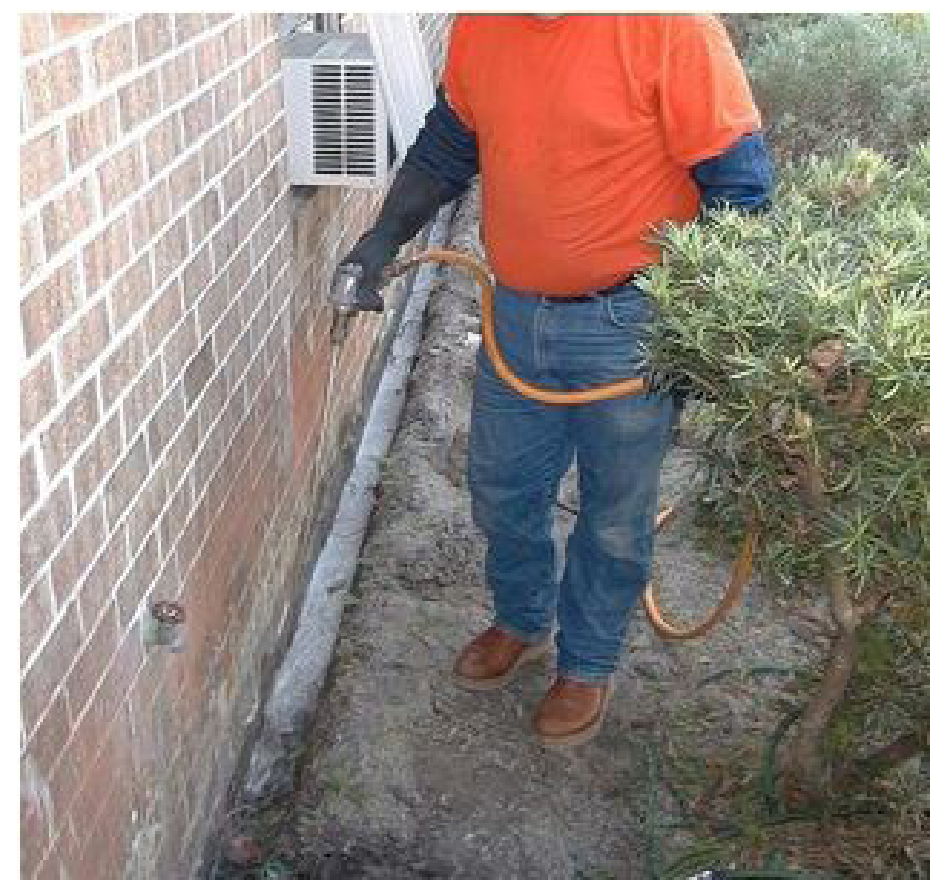

Figure 36. Applying the correct amount into the trench and drill holes requires that the pest management professional know how much termiticide is being sprayed at the end of the wand. They should have a rough idea of how many gallons per minute is being sprayed. Credits: Faith Oi, UF/IFAS

- Conehead (Nasutitermes corniger) and related termites do not respond to borates, so borates are not a recommended stand-alone new construction treatment.

\section{What You May See Your Pest Management Professional Do}

Most people who buy a new home will not see this phase of the treatment, but if you happen to be there during

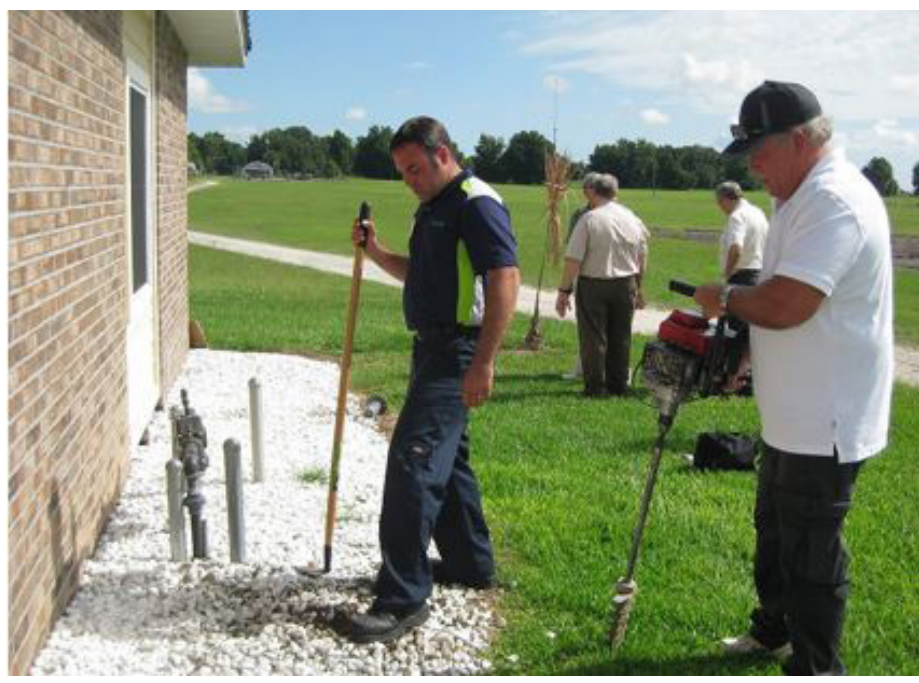

Figure 37. Pest management professionals deciding on where and how to drill the hole for the bait.

Credits: Faith Oi, UF/IFAS

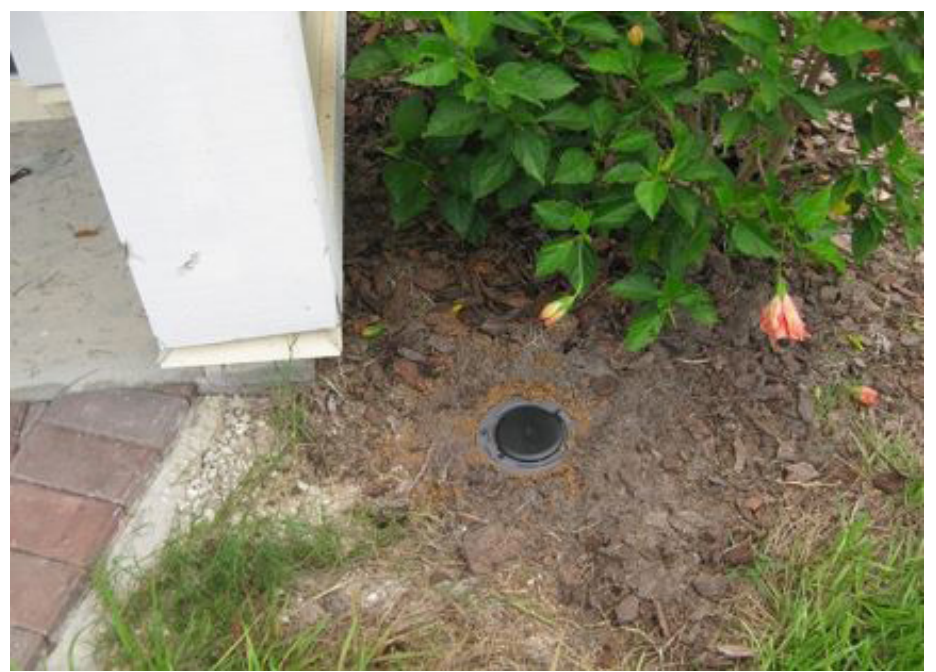

Figure 38. The installed bait housing.

Credits: Faith Oi, UF/IFAS

construction, you may witness it. The builder will call a pest management professional when the framing elements are installed and construction is at the "dried-in" phase. The pest management professional may opt to include a dye marker in the treatment preparation because the borate solution is clear. The label requires that the wooden members be treated to a minimum height of two feet (Figure 39).

One of the challenges of a borate treatment is that sometimes framing and other wooden elements are moved or added during the construction process, and this sometimes happens after the pest management professional has done the borate treatment. Unless the builder calls the pest management professional back to treat the modifications, neither the home buyer nor the pest management professional will know that some portions of the structure have not been treated (Figure 40). 


\section{Conehead Termites}

The conehead termites also have been called "tree termites." They are a particularly voracious invasive termite that is currently limited to portions of Broward County in south Florida but that may exist elsewhere. Please familiarize yourself with the pictures below and help limit the spread of this invasive termite. Do not attempt to self-treat.

The Florida Department of Agriculture and Consumer Services is leading an eradication effort that has been highly successful. The original site in Dania, FL, has been clear of conehead termites for one year, but diligent surveillance continues.

Homeowners in Florida can help in surveillance and eradication efforts by reporting this invasive termite if you suspect it is in your neighborhood. Please contact: 1-888-397-1517 For more information: https://www. freshfromflorida.com/Consumer-Resources/Healthand-Safety/Protect-Your-Home-from-Pests/Termites/ Conehead-Termite-Program.

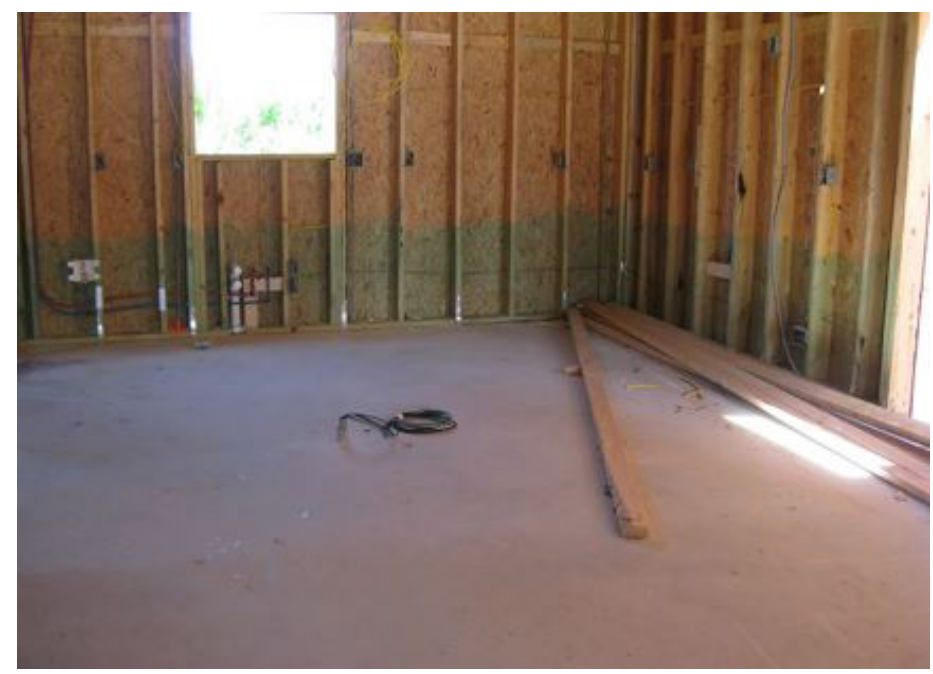

Figure 39. Borate-treated wall with a dye marker that shows where the treatment was applied.

Credits: Faith Oi, UF/IFAS

\section{Conclusion}

There are approximately 2,750 species of termites globally. Forty-five species have been found in the United States. Most of these termites are not harmful to homes or their contents. If you suspect that you have a termite problem, call a professional pest manager who has experience in termites and other wood-destroying organisms. You may find it beneficial to use more than one termite control method in conjunction with regular inspections and good building and home maintenance practices in your effort to keep your home termite-free.

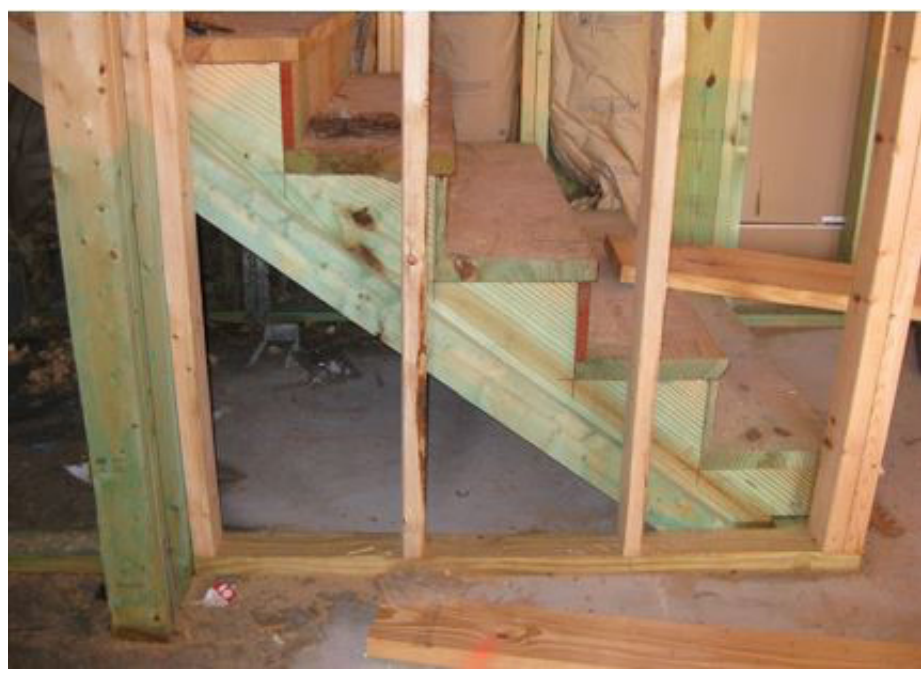

Figure 40. The dye marker shows that some wooden elements were treated, but the wall framing unit has likely been added since the treatment and is vulnerable to termites.

Credits: Faith Oi, UF/IFAS

\section{Homeowner Checklist}

- Prevent termites through regular home maintenance.

- Know how to detect termites in areas at risk.

- Identify termites correctly.

- Understand that controlling existing infestations is generally not a do-it-yourself project.

- Contact a licensed pest control company if you suspect termites on your property.

\section{References}

Global Invasive Species Database. 2019. Downloaded from http://www.iucngisd.org/gisd/100_worst.php on 18-07-2019

Parman, V., and E. Vargo. 2008. "Population Density, Species Abundance, and Breeding Structure of Subterranean Termite Colonies in and around Infested Houses in Central North Carolina." J. Econ. Entomol. 101: 1349-1359. Accessed July 18, 2019 https://doi.org/10.1093/jee/101.4.1349 Accessed July 18, 2019

Rust, M., and N.-Y. Su. 2012. "Managing Social Insects of Urban Importance." Annual Review of Entomology 57: 355-375. Accessed July 18, 2019 https://doi.org/10.1146/ annurev-ento-120710-100634

Scheffrahn, R., and N.-Y. Su. 2000. Florida Dampwood Termites. EENY-122. Gainesville: University of Florida Institute of Food and Agricultural Sciences. Reviewed: December 2017. https://edis.ifas.ufl.edu/in279 


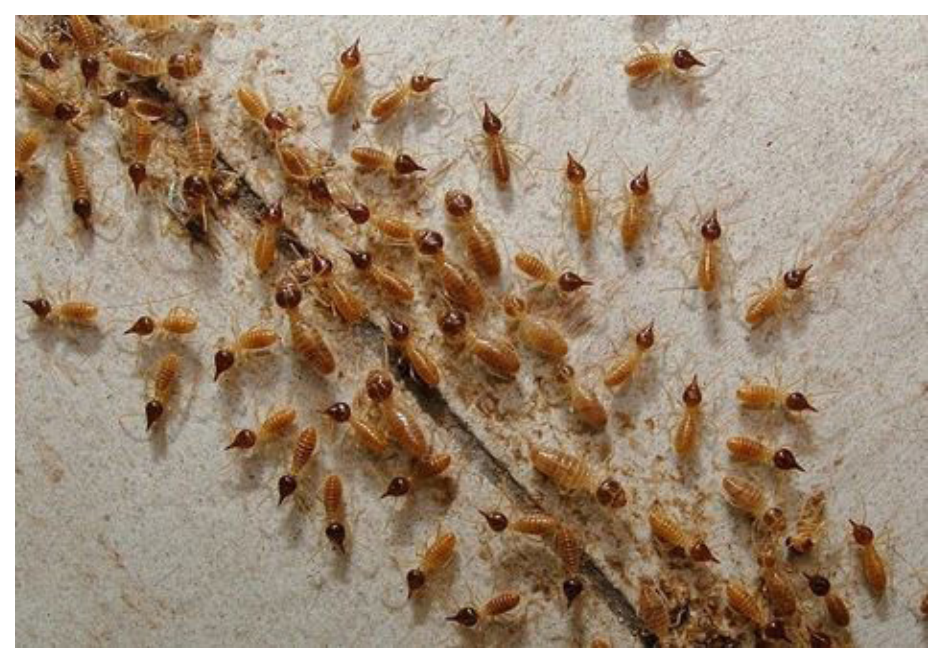

Figure 41. Conehead termite soldiers with snout-like projection mixed with worker termites. The snout-like projection can shoot out a sticky fluid as a defensive mechanism.

Credits: Rudolph Scheffrahn, UF/IFAS

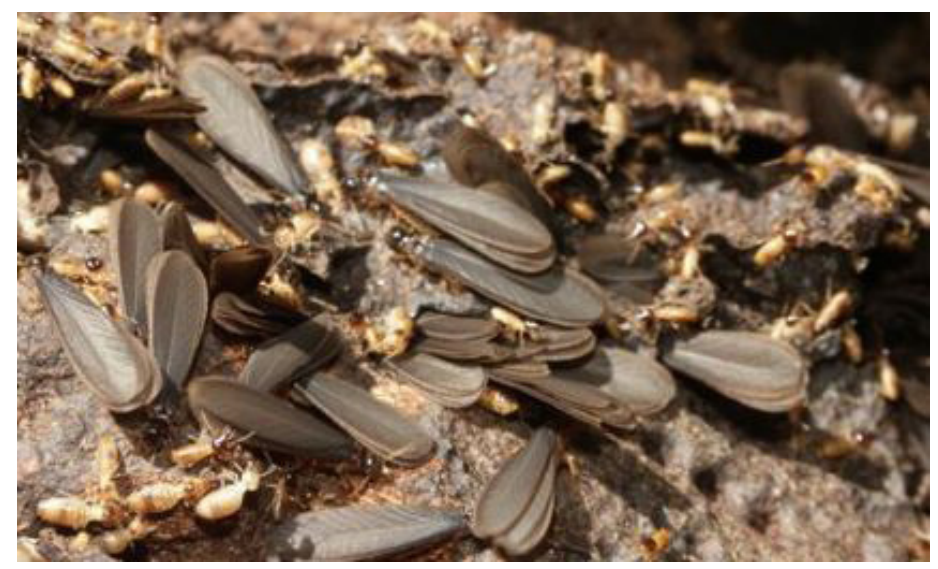

Figure 42. Conehead swarmers with dark wings.

Credits: FDACS

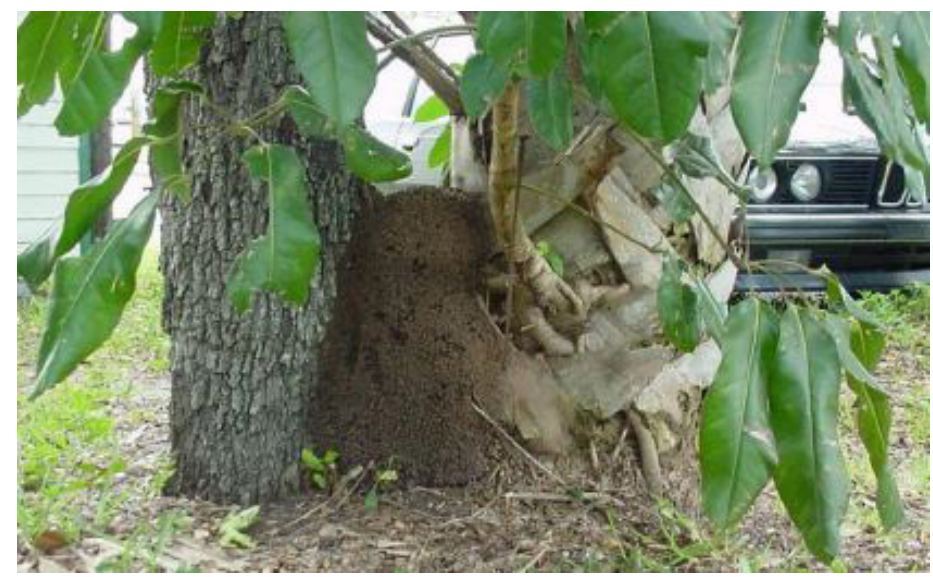

Figure 43. Conehead nest at base of tree. Nests can occur almost anywhere.

Credits: FDACS

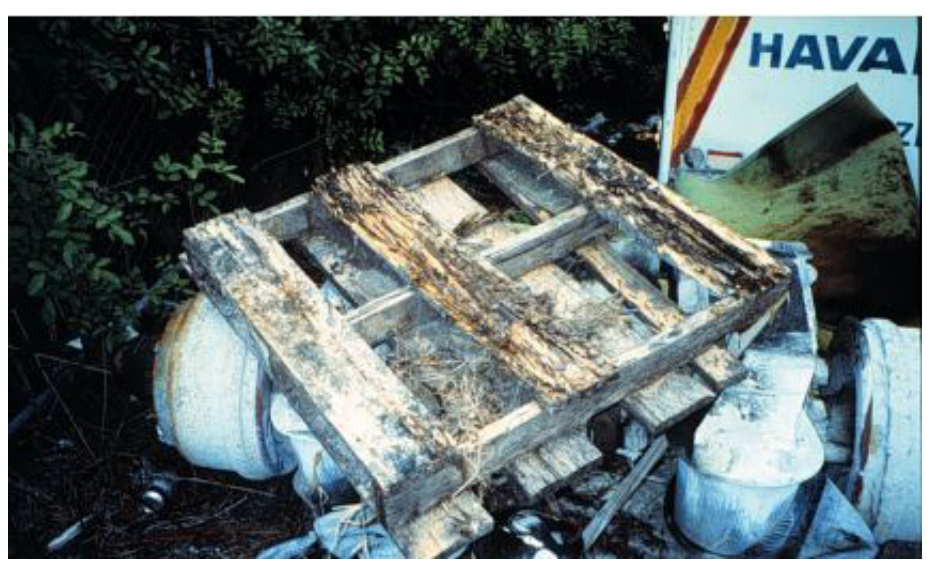

Figure 44. Conehead termites can infest anything made of cellulose, including wood and paper.

Credits: FDACS

\section{Acknowledgements}

This work is supported by the Crop Protection and Pest Management Extension Implementation Project, grant no. 2017-70006-27149/project accession no. 1013962 from the USDA National Institute of Food and Agriculture. We also thank the pest management professionals who generously shared their expertise: Bryce Hamilton, Linda Prentice, James Sneed. July 18, 2019. 
Table 1. Summary of control methods for subterranean termites, drywood termites, and wood-decay fungi.

\begin{tabular}{|c|c|c|c|c|}
\hline Method & Subterranean & Drywood & Decay Fungi & Longevity \\
\hline Soil termiticide & Yes & No & No & $2-15+$ years \\
\hline Baits & Yes & No & No & $\begin{array}{l}4-7+\text { years to indefinitely, } \\
\text { as long as system is } \\
\text { maintained }\end{array}$ \\
\hline $\begin{array}{l}\text { Wood preventative } \\
\text { treatment }\end{array}$ & Treated areas only & Treated areas only & Treated areas only & $10+$ years; inorganic salt \\
\hline Wood replacement & No & Yes, when localized & Yes, when localized & --- \\
\hline Physical barriers & Yes & No & No & $10+$ years \\
\hline
\end{tabular}

